\title{
Law-Making Activity in the Case Law of The Constitutional Court of Ukraine
}

\author{
Kristina Trykhlib \\ Yaroslav Mudryi National Law University, Ukraine \\ kristina.trihleb3105@ukr.net
}

TRYKHLIB, Kristina. Law-Making Activity in the Case Law of the Constitutional Court of Ukraine. International and Comparative Law Review, 2019, vol. 19, no. 2, pp. 27-75. DOI: 10.2478/iclr-2019-0014.

\begin{abstract}
Summary: The aim of this paper is to reveal and examine law-making elements in the jurisprudence of the Constitutional Court of Ukraine. It should be noted that the Constitutional Court has no direct powers to establish new legal norms under national legislation. However, in the process of constitutional interpretation, the case law of the Court demonstrates de facto the presence of law-making activity, that leads to the extension of its discretionary power on the formation of law. The paper will focus on the analysis of the practice of the Constitutional Court of Ukraine with regard to the 'creative interpretation' of law. A review of selected case law leads to a conclusion that the Constitutional Court often uses the dynamic interpretation of the Constitution. Moreover, the Court may change its own legal position in order to protect constitutional rights. Thus, the Constitutional Court of Ukraine has the right to 'develop' the law through evolutive interpretation of the Constitution. It can also be concluded that the Constitutional Court enjoys a wide 'margin of appreciation' in its interpreting of the Constitution.
\end{abstract}

Keywords: Constitutional Court, constitution, law-making activity, dynamic interpretation, development of law, creative interpretation, margin of appreciation, legal evolution, discretionary power, case law.

\section{Introduction}

The Constitutional Court of Ukraine (hereinafter - CCU) started its operation guided by the new Constitution of the independent Ukraine on October 18, 1996. On 1 January 1997, the CCU started accepting motions and constitutional petitions for consideration. ${ }^{1}$

It must be noted that starting from 2014, Ukraine has had a systemic overhaul of the country's political and legal system. Its primary focus is on the fullscale judicial reform. The reform started as a response to the popular demand for

1 Шаповал В. М. Конституційний Суд України. У Смолій В. А. (ред). Енциклопедія історії України. Київ: Наукова думка, 2008, Т. 5, с. 73 (SHAPOVAL, Volodymyr. The Constitutional Court of Ukraine. In SMOLII, Valerii (ed). Encyclopedia of Ukraine's History. Kyiv: Naukova Dumka, 2008, vol. 5, p. 73). 
an independent, fair justice based on the European standards of human rights protection.

The actual start of the reform was 2015 with the passage of the Law of Ukraine 'On Ensuring the Right to a Fair Trial'. In 2016 the legislators made respective amendments to the Constitution of Ukraine ${ }^{3}$ (with regard to the justice system), passed the new version of the Law of Ukraine 'On Judiciary and the Status of Judges', 'On the High Council of Justice. ${ }^{5}$ They were followed by the new Law of Ukraine 'On the Constitutional Court of Ukraine' passed in 2017, and the Law 'On the High Anti-Corruption Court' passed in 2018.'

It should be noted that today Ukraine is at the stage of reforming its national political and legal systems in accordance with the European standards, norms and principles of law. The role of the Constitutional Court in the interpretation of the Constitution as the Fundamental Law of the state and the ensuring of human rights and freedoms is fundamentally changing, which is, particularly, connected with the introduction of the constitutional complaint in Ukraine.

2 Закон України 'Про забезпечення права на справедливий суд' № 192-VIII від 12 лютого 2015 р. Відомості Верховної Ради (ВВР), 2015, № 18, № 19-20, ст.132 (The Law of Ukraine 'On Ensuring the Right to a Fair Trial' no. 192-VIII of 12 February 2015. Bulletin of the Verkhovna Rada of Ukraine, 2015, no. 18, no. 19-20, st.132). [online]. Available at: <https://zakon.rada.gov.ua/laws/show/192-19> Accessed: 19.10.2019.

3 Конституція України, прийнята 28 червня 1996 р., № 254к/96-ВР. Відомості Верховної Ради України (ВВР), 1996, № 30, ст.141 (Constitution of Ukraine, adopted 28 June 1996, no. 254K/96-BP. Bulletin of the Verkhovna Rada of Ukraine, 1996, no. 30, st.141). [online]. Available at: <https://zakon.rada.gov.ua/laws/show/254\%D0\%BA/96-\%D0\%B2\%D1\%80> Accessed: 19.10.2019.

4 Закон України 'Про судоустрій і статус суддів' № 1402-VIII від 02 червня 2016 р. Відомості Верховної Ради (ВВР), 2016, № 31, ст.545 (The Law of Ukraine 'On Judiciary and the Status of Judges' no. 1402-VIII of 2 June 2016. Bulletin of the Verkhovna Rada of Ukraine, 2016, no. 31, st.545). [online]. Available at: <https://zakon.rada.gov.ua/laws/ show/1402-19> Accessed: 19.10.2019.

5 Закон України 'Про Вищу раду правосуддя' № 1798-VIII від 21 грудня 2016 р. Відомості Верховної Ради (ВВP), 2017, № 7-8, ст.50 (The Law of Ukraine 'On the High Council of Justice' no. 1798-VIII of 21 December 2016. Bulletin of the Verkhovna Rada of Ukraine, 2017, no. 7-8, st.50). [online]. Available at: <https://zakon.rada.gov.ua/laws/ show/1798-19> Accessed: 19.10.2019.

6 Закон України ‘Про Конституційний Суд України’ № 2136-VIII від 13 липня 2017 р. Відомості Верховної Ради (ВВР), 2017, № 35, ст.376 (The Law of Ukraine 'On the Constitutional Court of Ukraine' no. 2136-VIII of 13 July 2017. Bulletin of the Verkhovna Rada of Ukraine, 2017, no. 35, st.376). [online]. Available at: <https://zakon.rada.gov.ua/laws/ show/2136-19> Accessed: 19.10.2019.

7 Закон України 'Про Вищий антикорупційний суд’ № 2447-VIII від 07 червня 2018 p. Відомості Верховної Ради (ВВР), 2018, № 24, ст.212 (The Law of Ukraine 'On the High Anti-Corruption Court of Ukraine' no. 2447-VIII of 7 June 2018. Bulletin of the Verkhovna Rada of Ukraine, 2018, no. 24, st.212). [online]. Available at: <https://zakon.rada.gov.ua/ laws/show/2447-19> Accessed: 19.10.2019. 
The legal foundation for the operation of the Constitutional Court of Ukraine is formed by the Constitution of Ukraine, the Law of Ukraine 'On the Constitutional Court of Ukraine', the CCU's Rules of Procedure and the Regulations 'On the CCU's Secretariat.'

Article 147 of the Constitution states that the main task of the Constitutional Court of Ukraine is to decide on the issues of conformity of the laws and other legal acts to the Constitution of Ukraine and provide the official interpretation of the Constitution of Ukraine. The CCU's operation is founded on the principles of the rule of law, independence, collegiality, publicity, reasonableness and binding effect of its decisions and opinions. ${ }^{9}$

Nowadays the role of the Constitutional Court in the formation and implementation of the European legal values has an extremely important theoretical and practical significance for the development of legal science and practice in Ukraine, as Ukraine identifies itself with the European civilization, the European Community. Herewith, the realization of the European legal values serves as the basis for the creation of the common European legal understanding, thinking and law-enforcement. Given the European aspirations of Ukraine, its membership in the Council of Europe, the realization and protection of the European legal values of democracy, the rule of law and human rights are an integral part of the functioning of the law-governed state. In this context the Constitutional Court must be one of the major subjects of the formation of modern legal doctrine. Currently the Constitutional Court of Ukraine promotes harmonization and convergence of the legal system of Ukraine with the European Values and standards of law.

So, the current practice (legal interpretations) by the CCU plays an extremely important role in the system of state government bodies, its decisions are not just binding, they are of authoritative and progressive nature stimulating the dynamic and integrating development of law.

Stanislav Shevchuk, the CCU Chairman, believes that the trust in Ukraine's court system can be restored by passing argumentative decisions that can be understandable for the people and useful in active communication with the public. "An individual in a democratic society is free, the purpose of the Constitution is to guarantee freedoms. This is the only way to build a constitutional democracy", stresses S. Shevchuk. ${ }^{10} \mathrm{He}$ also stated that human rights are inherent funda-

8 Положення Про Секретаріат Конституційного Суду України від 21 грудня 2011 року, затверджене Рішенням Конституційного Суду України № 26-p/2011. Офіційний вебсайт Конституиійного Суду України (Regulation 'On the Secretariat of the Constitutional Court of Ukraine' of 21 December 2011, adopted by the Decision of the Constitutional Court of Ukraine no. 26-p/2011. Official web-site of the Constitutional Court of Ukraine). [online]. Available at: <http://www.ccu.gov.ua/docs/179> Accessed: 19.10.2019.

9 The Constitution of Ukraine, adopted 28 June 1996, Chapter XII.

10 Голова Конституційного Суду України Станіслав Шевчук: "Конституція - це не 
mental rights protected by the Fundamental Law of the land. "The Constitution reflects not only the text, but values and the spirit as well. It is a sacred document and now is the time when everyone should learn to respect it". ${ }^{11}$

According to Stanislav Shevchuk, the CCU's key mission as a guarantor of the legality and justice is to protect the Constitution of Ukraine, which is the fundamental value of the Ukrainian society rather than a mechanism wielded by the authorities. "The Constitutional Court of Ukraine is the Court over any laws, that is why we are ready to protect the Constitution of Ukraine against any potential infringements by the state", emphasized the Chairman. ${ }^{12}$

\section{The nature and essence of law-making activity of the Constitutional Court in Ukraine}

\subsection{Doctrinal arguments: pro and contra}

The legal nature of acts passed by the Constitutional Court of Ukraine has been the subject of the studies by many Ukrainian legal scholars including S. Shevchuk, Ye. Yevhrafov, A. Selivanov, V. Tatsii, Yu. Todyka, M. Teslenko, V. Tykhyi, Yu. Bilousov, P. Tkachuk, V. Shapoval and others.

V. Tykhyi, for instance, believes that acts of the CCU are interpretative. They have the normative meaning since they have explanatory norms that do not constitute normative and legal acts. The functional intent of the decisions of the CCU on the official interpretation of the Constitution of Ukraine serves as a legal tool to ensure that the Constitution is understood and applied accurately and unambiguouslyn, making it one of the legal means to secure the constitutional legality and safeguard of the Constitution of Ukraine. ${ }^{13}$

Some lawyers make assumptions that the decisions of the CCU should be seen not as official acts of interpretation, they should rather be seen as judicial precedents that contain certain legal norms, because under the Constitution of Ukraine the decisions and opinions ruled by the Constitutional Court of Ukraine are binding, final and cannot be appealed. S. Shevchuk, for example, assesses them in the view of the judicial precedent doctrine ${ }^{14}$ and states:

лише текст, а й цінності та дух". Судова влада України, повідомлення прес-служби Cydy (SHEVCHUK, Stanislav. Chairman of the Constitutional Court of Ukraine: "The Constitution is not only a text, but values and the spirit as well". Judicial Power of Ukraine, messages of the Court's press service. [online]. Available at: <https://court.gov.ua/press/ news/481840/> Accessed: 19.10.2019).

11 Id.

12 Id.

13 Тихий В. П. Правова природа Конституційного Суду України, його повноваження, рішення та висновки. Право України, 2012, № 1-2, с. 97-111 (TYKHYI, Volodymyr. The Legal Nature of the Constitutional Court of Ukraine, I...ts Powers, Decisions and Conclusions. Law of Ukraine, 2012, no. 1-2, pp. 97-111).

14 Шевчук С. Щодо обов’язковості рішень Конституційного Суду України у контексті 
[...] in the states with Romano-Germanic law the official judicial precedent is not recognized as a source of law, though in practice it serves in the form of a concept of the 'constant jurisprudence' (Fr. jurisprudence constante), under which a series of the earlier adopted and authorized court decisions is viewed as compelling proof for the accurate interpretation of the legal norm (italic emphasis in the original). ${ }^{15}$

Ye. Yevhrafova notes that the CCU's decisions on finding laws and other legal acts unconstitutional is an element of the current legislation and in the hierarchy they take precedence over laws, i.e. they are second in line after the Constitution of Ukraine. ${ }^{16}$ Moreover, the special legal nature of the CCU's decisions is also conditioned by the fact that the decisions on the unconstitutionality of laws and other legal acts at the same time set the direction of legal policies pursued by the Parliament, the Head of State, the Cabinet of Ministers of Ukraine. ${ }^{17}$

At the same time a number of renowned legal scholars have been persistent in their support for the view that the CCU has a law-making function. For example, Yu. Shemshuchenko and V. Pohorilko identify a legislative (law-making) function among other functions of the CCU, it consists of 'negative law-making' and interpretations (italic emphasis in the original). ${ }^{18}$ At the same time the Parliament is responsible for the 'positive law-making'. The reasoning behind this view is that CCU's decisions on the unconstitutionality of legal acts revoke them, and so these decisions have the power of normative and legal acts. ${ }^{19}$ Thus, M. Teslenko notes that the law-making function of the CCU stems from its special status of a single body of constitutional oversight (review) in Ukraine that is author-

доктрини судового прецеденту. Право України, 2000, № 2, с. 45-48 (SHEVCHUK, Stanislav. On the Binding Nature of the Decisions of the Constitutional Court of Ukraine Within the Context of the Doctrine of Judicial Precedent. Law of Ukraine, 2000, no. 2, pp. 45-48).

15 Шевчук С. В. Загальнотеоретичні проблеми нормативності актів судової влади: автореф. дис. ... д-ра юрид. наук: 12.00.01, Національна юридична академія України імені Ярослава Мудрого, Харків: [б. в.], 2008, с. 23 (SHEVCHUK, Stanislav. General Theoretical Problems of Normativity of the Judicial Power Acts: Abstract of the Thesis for the Doctor Habilitatus degree: 12.00.01, Yaroslav the Wise National Law Academy of Ukraine, Kharkiv, 2008, p. 23).

16 Євграфова Є. Акти Конституційного Суду України в системі національного законодавства. Право України, 2001, № 10, с. 66-68 (YEVHRAFOVA, Yelyzaveta. Acts of the Constitutional Court of Ukraine Within the System of the National Legislation. Law of Ukraine, 2001, no. 10, pp. 66-68).

17 Id.

18 Шемшученко Ю. С., Погорілко В. Ф. Проблеми функцій Конституційного Суду України. Вісник Конституційного Суду України, 2002, № 2, с. 54-56 (SHEMSHUCHENKO, Yurii, POHORILKO, Viktor. On Problems of Functions Performed by the Constitutional Court of Ukraine. Constitutional Court Ukraine Bulletin, 2002, no. 2, pp. 54-56).

19 TYKHYI, Volodymyr, 2012. 
ized by the Constitution to adopt acts of the universally binding nature. ${ }^{20} \mathrm{How}$ ever, these decisions do not create legal norms, which is not inherent in the CCU's mission and powers, they only 'remove' from the legislative system those acts that contradict the Constitution of Ukraine (italic emphasis added). ${ }^{21}$ It should be noted in this respect that the content of these decisions and opinions, primarily those on the official interpretation of the norms of the Constitution of Ukraine, are of the derivative nature in this sense that they do not exist independently of the respective norms (because the duration of the time effect that the CCU's decisions have is determined by the effect of the norm being interpreted), ${ }^{22}$ and they can be duly accounted only in the process of the application of law with regard to the Constitutional provisions. ${ }^{23}$

At the same time V. Shapoval argues that "it would be too categorical to assert that such decisions and opinions of the Constitutional Court of Ukraine are legal acts" (italic emphasis added). ${ }^{24}$ It is with this particular concept of the 'negative/ positive' legislator that the problem of denying the normative features of the CCU's decisions is associated with. For example, O. Skrypniuk, ${ }^{25}$ and V. Shapoval believe that the recognition of the law-making nature present in the CCU's decisions and opinions would place the Court above the whole state mechanism and even

20 Тесленко М. В. Конституційна юрисдикція в Україні. Київ: Школа, 2003, с. 39 (TESLENKO, Myroslava. Constitutional Jurisdiction in Ukraine. Kyiv: Shkola, 2003, p. 39).

21 Мартинюк Р. Правова природа та юридичні характеристики актів Конституційного Суду України. Підприємництво, господарство і право, 2008, № 1, с. 3-6 (MARTYNIUK, Roman. The Legal Nature and Judicial Characteristics of the Acts of the Constitutional Court of Ukraine. Entrepreneurship, Economy and Law, 2008, no. 1, pp. 3-6).

22 Тихий В. Правотлумачення Конституційним Судом України та правова природа його рішень. Вісник Конституційного Суду Украӥни, 2001, № 1, с. 66; див. також Тихий В. Дія рішень Конституційного Суду України в часі. Вісник Конституційного Суду України, 2001, № 5, с. 51 (ТYКНYI, Volodymyr. Judicial Interpretations by the Constitutional Court of Ukraine and the Legal Nature of Its Decisions. Constitutional Court Ukraine Bulletin, 2001, no. 1, p. 66; see also TYKHYI, Volodymyr. The Effect of the Decisions by the Constitutional Court of Ukraine Over Time. Constitutional Court Ukraine Bulletin, 2001, no. 5, p. 51).

23 MARTYNIUK, Roman, 2008.

24 Шаповал В. Концепція конституційного суду або відповідного інституту, що здійснює конституційний контроль, як 'негативного' та 'позитивного' законодавця. У Національна доповідь Конституційного Суду України на тему: 'Проблеми законодавчих прогалин в конституційній юриспруденції, с. 5 (SHAPOVAL, Volodymyr. The concepts of the Constitutional Court or the corresponding institution which implements the constitutional control as a 'negative' and 'positive' legislator. In the National Report of the Constitutional Court of Ukraine 'On the Problems of Legislative Omission in Constitutional Jurisprudence', p. 5). [online]. Available at: <http://www.confeuconstco.org/ reports/rep-xiv/report_Ukraine_uk.pdf> Accessed: 1.5.2019.

25 Скрипнюк О. В. Правові акти Конституційного Суду України як джерела сучасного конституційного права України. Право України, 2012, № 3-4, с. 404-410 (SKRYPNIUK, Oleksandr. Legal Acts of the Constitutional Court of Ukraine as a Source of the Modern Constitutional Law in Ukraine. Law of Ukraine, 2012, no. 3-4, pp. 404-410). 
the Constitution itself. ${ }^{26}$ At the same time it must be noted that the Ukrainian doctrine has not studied the CCU's operation in terms of 'activism,' 'moderation', 'minimalism.'27

In his turn V.M. Shapoval believes that the CCU's decisions and opinions cannot have the nature of normative and legal acts that have the capacity to actively regulate public relations. ${ }^{28}$ The competence of the Constitutional Court of Ukraine determined by the Constitution and the legislation does not provide for law-making other than that of regulating some issues with regard to the organization of its own operation. ${ }^{29}$ At the same time it does not preclude the acts by the CCU on the official interpretation of the Constitution of Ukraine from being recognized as those having a normative nature in the sense of their function to clarify the current Ukrainian laws without being directly and independently involved in the regulation of public relations, nevertheless, they do have effect on the formation and development of the national legal system.

Retired CCU Judge M. Koziubra notes that with the guide of its specific nature the constitutional jurisdiction should be dominated not by the adversarial principle, but rather the research principle. Still the research should not be taken in its absolute form and the operation of the Court should not be seen as tantamount to that of an academic or research institution. The thing is that in the process of developing a decision to provide a comprehensive consideration of the case the CCU takes into account both the legal position of individual bodies of state government and the opinion of recognized scholars. ${ }^{30}$ In this way the official interpretation of constitutional norms naturally combines legal and doctrinal

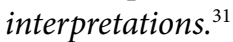

26 Шаповал В. Становлення конституційної юрисдикції в Україні. Правова держава, 1998, Вип. 9, с. 110-116 (SHAPOVAL, Volodymyr. Establishment of the Constitutional Jurisdiction in Ukraine. Constitutional State, 1998, no. 9, pp. 110-116).

27 SKOMOROKHA, Viktor, PSHENYCHNYI, Ihor. The concepts of the Constitutional Court or the corresponding institution which implements the constitutional control as a 'negative' and 'positive' legislator. In the National Report of the Constitutional Court of Ukraine 'On the Problems of Legislative Omission in Constitutional Jurisprudence', p. 5.

28 Шаповал В. Становлення конституціоналізму в Україні: проблеми теорії. Право України, 1998, № 5, с. 29 (SHAPOVAL, Volodymyr. Establishment of the Constitutionalsim in Ukraine: Theoretical Problems. Law of Ukraine, 1998, no. 5, p. 29).

29 National Report of the Constitutional Court of Ukraine 'On the Problems of Legislative Omission in Constitutional Jurisprudence', 21 p. [online]. Available at: $<$ http://www.confeuconstco.org/reports/rep-xiv/report_Ukraine_uk.pdf> Accessed: 19.10.2019.

30 Гончаров В. Від старої теорії тлумачення до нової: основні виклики та рішення. Філособія права і загальна теорія права, № 1. - 2/2014, с. 53-69 (HONCHAROV, Volodymyr. From the Old to the New Theory of Interpretation: the Main Challenges and Solutions. Philosophy of Law and the General Theory of Law, 2014, no. 1-2, pp. 53-69).

31 Топчій В.В. Офіційне тлумачення конституційних норм щодо прав людини у парадигмі юридичної герменевтики. Публічне право, 2016, № 1 (21), с. 276-283 (ТОРCHII, Vasyl. The Official Interpretation of the Constitutional Provisions of Human Rights in the Paradigm of Legal Hermeneutics. Public Law, 2016, no. 1 (21), pp. 276-283). 
The output of the CCU's influence could take the form of an actual revocation of the 'accountable' legal acts generating the positive effect on the law-making by the respective authorized bodies. And this is particularly the reasoning for a well-known thesis stating that the activity of the Constitutional Court of Ukraine can be relatively defined as 'negative law-making' (italic emphasis added). ${ }^{32}$ This 'negative law-making' by the CCU stems from the need to ensure an effective operation for the principle of the separation of powers that requires the availability of an independent referee with the exclusive competence to operate the system of checks and balances. ${ }^{33}$

Through this process the CCU exercises a priori (preventative) and a posteriori (repressive) control. A priori (preventative) control extends to two categories of cases: 1) on petitions from the President of Ukraine or the Cabinet of Ministers of Ukraine the CCU provides opinions on conformity to the Constitution of Ukraine of applicable international treaties of Ukraine or of international treaties submitted to the Verkhovna Rada of Ukraine for its consent to a binding nature thereof; on petitions of the Verkhovna Rada of Ukraine the CCU renders opinions on conformity to the requirements of Articles 157 and 158 of the Constitution of Ukraine of a draft law with amendments to the Constitution of Ukraine. A posteriori (repressive) control is exercised by the CCU in the following cases: on conformity to the Constitution of Ukraine of laws and other legal acts by the Verkhovna Rada of Ukraine, acts of the President of Ukraine, acts of the Cabinet of Ministers of Ukraine, legal acts of the Verkhovna Rada of the Autonomous Republic of Crimea; on the conformity to the Constitution of Ukraine of applicable international treaties; observance of the constitutional procedure for investigating and considering a case on removal of the President of Ukraine from office through impeachment; violation by the Verkhovna Rada of the Autonomous Republic of Crimea of the Constitution of Ukraine or laws of Ukraine in case of the early termination of its powers pursuant to the decision of the Verkhovna Rada of Ukraine. It is primarily with the a posteriori control over constitutionality when the problems of legislative gaps arise. Systemic analysis into the legal acts during the consideration of a case gives the grounds for the CCU to highlight the presence of certain legislative gaps. If the provisions of normative and legal acts are found unconstitutional they lose their effect on the date of the decision made by the CCU. ${ }^{34}$

32 Цвік М. В. Про систему юридичних актів. Вісник Академії правових наук, 2002, № 4 (31), c. 18 (TSVIK, Marko. On the System of Judicial Acts. Journal of the National Academy of Legal Sciences of Ukraine, 2002, no. 4 (31), p. 18).

33 MARTYNIUK, Roman, 2008.

34 Дослідження та оцінка конституційності законодавчих прогалин. Особливості дослідження законодавчих прогалин (Investigation and assesment of the constitutionality of legislative ommision. Peculiarities of the investigation of legislative omission. In the National Report of the Constitutional Court of Ukraine 'On the Problems of Legislative Omission in Constitutional Jurisprudence', p. 13). 
At the same time V. Topchii notes that the existence of a hermeneutic circle extrapolated on the operational procedure by the official interpretation of the Constitution, makes it possible to introduce into scientific circulation the term of 'constitutional and hermeneutic process' (italic emphasis added), it may be defined as "a scientifically substantiated multi-component intellectual and creative interpretation process by the authorized subjects of law and scholars studying the text of the Constitution with the account for the discourse of its establishment with the aim of identifying the relevant senses in constitutional norms to secure the further enhancement of the law enforcement operation". ${ }^{35}$ At the same time the scholar underscores that the process of the official interpretation of norms spelled out in the Constitution of Ukraine not only serves the purpose of addressing legal collisions that arise in the process of law enforcement, it makes the recurrence of this situations in future impossible. Thus, "[...] the constitutional and hermeneutic process is of the indicating, imperative and preemptive nature concurrently, otherwise the operation of the Constitutional Court of Ukraine would have lost its sense to some extent". ${ }^{36}$

At the same time we also have to be mindful of the value-setting role played by the CCU, it creates the capacity to accumulate value-based reference points of law as a social and cultural phenomenon, re-frame and interpret legal norms within the context of their relations with the respective value-based reference points in the domain of law. In addition, the CCU has an inherent system-making role of interpreting the Constitution of Ukraine in the context of the unity of legal norms spelled out in the Constitution; the results of these interpretations will have a universally binding nature for the future work in the field of interpreting and applying the law by other subjects of law. ${ }^{37}$

Some scholars suggest using a percieved intent of an abstract 'ideal' legislator as a guide. It means that the interpretation of law should be based not on the question of what, for example, the 226 People's Deputies had in mind when they were pushing buttons in the session hall (it is almost impossible to give an answer to this question), instead the question should deal with the intent of an 'ideal' legislator while formulating the respective regulation. ${ }^{38}$

In addition, in the process of analyzing cases, the CCU refers to the practice of the European Court of Human Rights (especially recently, particularly after

35 TOPCHII, Vasyl, 2016, pp. 276-283.

36 Id.

37 Котенко М. В. Роль системного тлумачення в правоінтерпретаційній діяльності Конституційного суду України. Часопис Київського університету права, 2015, № 2, c. 61-67 (KOTENKO, Mykola. Systematic interpretation and its role in the law-interpretational activities of the Constitutional Court of Ukraine. Scientific Journal "Chronicles of KUL", 2015, no. 2, pp. 61-67).

38 Мірошниченко А. М. Статичне та динамічне тлумачення права. Право і громадянське суспільство, 2012, № 1, с. 59 - 66 (MIROSHNYCHENKO, Anatolii. Static and Dynamic Interpretation of Law. Law and Civil Society, 2012, no. 1, pp. 59-66). 
the adoption of the Law of Ukraine 'On the Fulfillment of Decisions and Application of Practice of the European Court of Human Rights'). ${ }^{39}$ Namely, Chapter 4 of the Law ('Application of the Convention and the Practice of the Court in Ukraine') and Article 17 clearly say that in the consideration of cases the courts of Ukraine are to use the European Convention on Human Rights (ECHR) and the practice of the European Court of Human Rights (ECtHR) as the respective sources of law. ${ }^{40}$ Moreover, the representative body is bound to undertake legal examination (standpoint) of all the draft laws and subordinate normative acts that are subject to state registration, in order to establish their conformity to the ECHR, a special report is to be drafted based on the findings of this examination. A failure to undertake this examination or a report finding the non-conformity of the subordinate normative act to the ECHR requirements constitutes the grounds to reject the registration of the respective subordinate act. At the same time the Parliament is required to ensure the continuous and reasonable periodical review of applicable laws and subordinate acts to establish their conformity with the ECHR and the practice of the ECtHR, primarily in the areas of law enforcement, criminal proceedings, deprivation of liberty. Based on the findings of the review, the representative body submits to the Cabinet of Ministers of Ukraine (the government) proposals on amending the applicable laws and subordinate acts to bring them in conformity to the ECHR requirements and the respective practice of the ECtHR. In their turn the Ministries and other bodies of the central executive state government are responsible for undertaking systemic control over the exercise within their subordinate agencies the administrative practices to ensure their conformity with the ECHR and the practice of the ECtHR. ${ }^{41}$

According to P. Yevhrafov and V. Tykhyi, the use of the legal interpretations of the ECtHR by national courts, including the Constitutional Court of Ukraine, is mandatory under Article 31, III b) of the Vienna Convention on the Law of Treaties (1969) as per the following practice of the application of the Treaty. ${ }^{42}$ At the same time the scholars note that the ECHR norms and supplementing Protocols have been used as examples in the process of formulation and adoption of the Constitution of Ukraine. In this way the interpretations by the ECtHR should

39 Закон України 'Про виконання рішень та застосування практики Європейського суду з прав людини' від 23 лютого 2006 р. № 3477-IV. Відомості Верховної Ради України (ВВР), 2006, № 30, ст.260 (The Law of Ukraine 'On the Fulfillment of Decisions and Application of Practice of the European Court of Human Rights' of 23 February 2006 no. 3477-IV. Bulletin of the Verkhovna Rada of Ukraine, 2006, no. 30, st.260). [online]. Available at: <https://zakon.rada.gov.ua/laws/show/3477-15> Accessed: 19.10.2019.

40 Id., Art. 17.

41 Id., Art. 19.

42 Євграфов П. Правотлумачна діяльність Європейського суду з прав людини і іï значення для України. Jurisprudentia: інтернет-видання 'Юриспруденція оn-line' (YEVHRAFOV, Pavlo. Judicial Interpretations by the European Court of Human Rights and Their Significance for Ukraine. Jurisprudentia: Internet-Edition 'Jurisprudence on-line'. [online]. Available at: <https://www.lawyer.org.ua/?i=12> Accessed: 19.10.2019. 
also be used in the interpretations of the respective norms of the Constitution of Ukraine. In addition, under Protocol No. 2 to the ECHR, conferring upon the European Court of Human Rights competence to give advisory opinions, the ECtHR can upon request from the Committee of Ministers of the Council of Europe provide advisory opinions on legal issues with regard to the interpretation of the ECHR and supplementing Protocols. These opinions constitute recommendations by experts, i.e. they do not have a legally binding nature and considerably differ by its interpretation object from the interpretations by the ECtHR in its consideration of cases involving the violations of the ECHR. The use of reasoned opinions by the European Court of Human Rights that comprises of respected legal scholars, is justified. ${ }^{43}$

In his turn, S.Shevchuk lists the following approaches to the use of the practice of the ECtHR by the Constitutional Court of Ukraine in order to substantiate its own legal positions: 1) 'reference' method - the CCU makes brief references to the existence of certain European standards with regard to the matter in question without providing any details, i.e. without citing specific articles from the ECHR or decisions of the ECtHR; 2) 'casuistry' - the CCU cites specific articles of the ECHR as well as the list of respective decisions; 3 ) the 'casuistry-content' method - the reference is made not only to the specific article of an international treaty or court's decision, but rather to its extended content. ${ }^{44}$

\subsection{Establishing legal norms. Are there any manifestations of law-making acti-} vity in the case law of the Constitutional Court of Ukraine?

The issue regarding the 'establishment' of legal norms by the CCU is a debated one within the national legal doctrine. There is a number of factors behind that. For instance, Ukraine's legal system tends to be closer to the Romano-Germanic legal family where the overwhelming majority of states recognize the normative and legal act as the primary and binding source of law, while in the classification of the sources of law, the court precedent, at least formally, is a secondary and rather persuasive source of law. In the words of A. Selivanov, "Ukrainian court practice tends to see the court precedent as an element of lawyers' professional conscience that they use as some sort of guidance in legal thinking to decide on court disputes" ${ }^{45}$ At the same time, recent globalization and integration pro-

43 Id.

44 Шевчук С. В. Загально-теоретичні проблеми нормативності актів судової влади [Текст]: дис. ... д-ра юрид наук : 12.00.01, Нац. юрид. акад. України ім. Ярослава Мудрого. - Харків, 2008, с. 318 - 319 (SHEVCHUK, Stanislav. General Theoretical Problems of Normativity of the Judicial Power Acts [Text]: Thesis for the Doctor Habilitatus degree: 12.00.01, Kharkiv, Ukraine: Yaroslav Mudryi National Law Academy, 2008, p. 318 $-319)$.

45 Селіванов А. О., Стрижак А. А. Питання теорії конституційного правосуддя в Україні: актуальні питання сучасного розвитку конституційного правосуддя. Київ: Логос, 2010, с. 103 (SELIVANOV, Anatolii, STRYZHAK, Andrii. On Theoretical Issues of Constitutional Justice in Ukraine: Relevant Questions on the Current Development of the 
cesses have contributed to the convergence of not only different legal systems, but of legal families as well. This process is fueled primarily by the needs of the legal practice and the necessity to develop and adjust the law to meet the modern needs of society and to protect human rights.

Ukraine does not have a system of the sources of law established de jure at the legislative level. This model has been developed within the legal doctrine instead. It is believed that the judicial power cannot establish new legal norms as it will contradict the principle of the separation of powers. So, in the Resolution of the CCU of 30 November 2006, regarding the rejection to initiate constitutional proceedings in the case involving the constitutional petition made by 46 People's Deputies of Ukraine concerning the conformity to the Constitution of Ukraine of Clause 17 in the Methodology of Calculating and the Procedure of Using the Payments Received in Return for the Lease of State Property as per the Decree of the Cabinet of Ministers of Ukraine of 4 October 1995 no. 786, and regarding other issues in this petition the CCU stated that the Court "[...] has no authority to change or amend acts of the applicable laws of Ukraine. Article 6 of the Constitution of Ukraine stipulates that, 'State power in Ukraine is exercised on the principles of its division into legislative, executive and judicial power. [...] Article 75 of the Constitution of Ukraine makes the Ukrainian Parliament, the Verkhovna Rada of Ukraine, the sole body of legislative power in Ukraine"' ${ }^{46}$

Hence the courts are only to apply the law and consequently any acts and decisions by courts deal with applying the norms instead of making them. That is why the Doctrine is dominated by the opinion that CCU's acts of interpreting the Constitution are of an interpretative and law-applying nature. In my opinion, though, the sensu stricto division of power between the legislative, executive and judicial branches of government is impossible and not advisable, since each of the branches has certain powers to adopt normative acts (normative competence), i.e. basically legal norms. This division should be viewed in the sense that only the Parliament has the right to pass the laws which is its key prerogative. In this regard it must be noted that under the new Law 'On the Constitutional Court of Ukraine', CCU is currently engaged exclusively with the interpretation of the Constitution of Ukraine, though it used to provide official universally binding interpretations on the laws of Ukraine as well, it could have undermined the effectiveness with which the system of checks and balances operated within the current model of the separation of powers. In this regard there are debates on the legal essence that different sources of law have, including the CCU's acts as a special body of constitutional jurisdiction. These debates are also fueled by the question of the place and the status of the Court within the system of the state government bodies and, consequently, the legal nature of its acts. It stems from,

Constitutional Justice. Kyiv: Lohos, 2010, p. 103).

46 Resolution of the Constitutional Court of Ukraine of 30 November 2006 no. 16-y/2006. [online]. Available at: <https://zakon.rada.gov.ua/laws/show/v016u710-06/sp:max25> Accessed: 19.10.2019. 
primarily, the special role that the CCU plays, i.e. ensuring the supremacy of the Constitution of Ukraine. ${ }^{47}$ Among the state government bodies the CCU has a special place and a special role in the work of the system of checks and balances (the role of a referee).

Under the Constitution of Ukraine, a decision or an opinion of the CCU shall be binding, final and may not be appealed. While laws, other acts or some of their provisions that were declared unconstitutional, lose their effect from the day of the adoption by the Court of a decision declaring their unconstitutionality, unless otherwise provided by the same decision, but not earlier than the date of its adoption. ${ }^{48}$ In addition, Article 8 of the Constitution of Ukraine specifies, "In Ukraine, the principle of the rule of law is recognized and effective. The Constitution of Ukraine has the highest legal force. Laws and other normative legal acts are adopted on the basis of the Constitution of Ukraine and shall conform to it" ${ }^{49}$ That is why we arrive to a logical question whether there is any need to compare acts of the CCU with other acts, those passed by the Parliament, for instance. I am confident that we have to abandon the mechanistic approach to developing classifications and artificial models of the sources of law, we should focus instead on their practical effects, the effectiveness and the role that the CCU has in the development of the legal system, making it more flexible and capable to adjust to the needs and meet the challenges.

\subsubsection{Examples of 'law-making' elements in the case law of the Constitutional} Court of Ukraine and their impact on the understanding and application of constitutional principles, human rights and freedoms

A vivid illustration of the law-making activity of the Constitutional Court of Ukraine at the constitutional level is the Decision by the CCU of 30 September 2011, no. 20-rp/2010, with which the Court changed the form of state government in Ukraine transforming it from the parliamentary-presidential into the presidential-parliamentary republic..$^{50}$ In its decision the CCU declared unconstitutional the Law of Ukraine 'On Introducing Amendments to the Constitution of Ukraine' of 8 December 2004, no. 2222 (it established the parliamentary-presidential form of state government), referring to violations in the constitutional procedure when the Law was considered and adopted. Thus, the CCU established that Ukraine would be governed by the Constitution in the version of 1996 that established the presidential-parliamentary republic as the form of state government in Ukraine. ${ }^{51}$

47 The Law of Ukraine 'On the Constitutional Court of Ukraine' of 13 July 2017, Art. 1.

48 The Constitution of Ukraine, adopted 28 June 1996, Arts. 151 ${ }^{-2}, 152$.

49 Id., Art. 8.

50 Decision of the Constitutional Court of Ukraine of 30 September 2010 no. 20-rp/2010. [online]. Available at: <https://zakon.rada.gov.ua/laws/show/v020p710-10> Accessed: 19.10.2019.

51 Id. 
With this Decision the CCU assumed the exclusive powers of the Parliament in part of amending the Constitution of Ukraine. This Decision of the Court was criticized not only by the Ukrainian but also by the international community. Namely, the European Commission for Democracy through Law (Venice Commission) stated in its Decision that the return to the Constitution of Ukraine in the version of 1996 pursuant to the CCU's Decision

raises questions of legitimacy with respect to the present state institutions, since the President and the Parliament were elected under constitutional rules that are no longer recognized as valid. The President of Ukraine, as from this judgment, enjoys far more powers than could be foreseen by the voters when he was elected. The working of the main state organs is now based on rules changed by a court and not on rules changed by the Verkhovna Rada, as a democratically legitimate body. ${ }^{52}$

\subsubsection{The death penalty case}

Another important decision by the CCU that features some clear elements of law-making at the sub-constitutional (statutory) level is the Decision of 29 December 1999, no. 11-rp/99 (the death penalty case), ${ }^{53}$ in which the Constitutional Court of Ukraine decided that the provisions of Article 24 of the General Part and the provisions of the sanctions specified by the Special Part of the Criminal Code of Ukraine, that provide for death penalty as a type of punishment, contradict with the Constitution. At the same time, the Constitutional Court stated that the key consideration in the recognition of an individual's right to life under the Constitution of Ukraine are the provisions stating that this right is integral, inalienable and non-derogable.

A person has the right to life from birth and it is protected by the state. [...] Taking the human life by the state as the result of a death penalty as a type of punishment, even within the provisions specified by the law, is a derogation of the integral human right to life, it contradicts the Constitution of Ukraine ('emphasis added'). ${ }^{54}$

The CCU's role in the mechanism of protecting human rights and freedoms is of particular interest. Some scholars (O. Kalinichenko, O. Klymovych, R. Martyniuk, I. Petriv and others) believe that the function of protecting human rights and freedoms is not intrinsic with the CCU, others (A. Husiev, A. Selivanov,

52 Opinion of the Venice Commission On the Constitutional Situation in Ukraine no. 599/2010 of 17-18 December 2010 (CDL-AD(2010)04), p. 11. [online]. Available at: <https://www. venice.coe.int/webforms/documents/default.aspx?pdffile $=$ CDL-AD(2010)044-e $>$ Accessed: 19.10.2019.

53 Decision of the Constitutional Court of Ukraine of 29 December 1999 no. 11-rp/99. [online]. Available at: <https://zakon.rada.gov.ua/laws/show/v011p710-99> Accessed: 19.10.2019.

54 Id. 
A. Stryzhak, V. Tykhyi) are of the opinion that this function is inherent in the Court's functioning. At the same time the majority of academics are arguing that the protection of human rights starts with legal understanding, hence there is no reason to reduce the function of protecting human rights only to the passage of certain normative and legal acts, oversight of the observance of some provisions in laws and bylaws or consideration of cases involving specific offenses in this field. ${ }^{55}$ Since the CCU plays a humanistic role that consists of ensuring human rights and freedoms while ascertaining and clarifying the content and the sense of legal norms to be interpreted, ${ }^{56}$ especially within the context of considering constitutional complaints.

\subsubsection{Case of involuntary hospitalization of incapable persons to a mental} health institution

An extremely important and even a landmark decision in the development of Ukraine's legal system is the Decision by CCU no. 2-rp/2016 of 1 June 2016, in the case involving the constitutional petition of the Ukrainian Parliament Commissioner for Human Rights on the conformity to the Constitution of Ukraine of Paragraph 1, Article 13 of the Law of Ukraine 'On Psychiatric Aid' (the case involving judicial review over hospitalization of incapable persons to a mental health institution)..$^{57}$

The subject of the right to constitutional petition - the Ukrainian Parliament Commissioner for Human Rights - petitioned the CCU with a motion to declare unconstitutional the provision of the Law of Ukraine 'On Psychiatric Aid' of 22 February 2000, under which a legally incompetent person, can be admitted involuntarily (committed) to a mental health institution only at the request or with the consent of his or her guardian. The provision of this Law made it possible for admitting a legally incompetent person to a mental facility without a court decision taken on the grounds of a legal examination into the substantiation of and necessity for an involuntary hospital admission of this sort. In the opinion of the subject of the right to constitutional petition, an admission of a legally incompetent person to a mental facility at the request or with the consent of his or her guardian without a court decision contradicts the Constitution of Ukraine and is an act of deprivation of liberty within the context of Article 5 IV ECHR, since this person is held in a constrained space for a long time without this person's informed consent. ${ }^{58}$

55 TOPCHII, Vasyl, 2016, pp. 276-283.

56 KOTENKO, Mykola, 2015, pp. 61-67.

57 Decision of the Constitutional Court of Ukraine of 1 June 2016 no. 2-rp/2016. [online]. Available at: <https://zakon.rada.gov.ua/laws/show/en/v002p710-16\#n17> Accessed: 19.10.2019.

58 Id. 
In the decision on this case the CCU stated that

[...] any restrictions in the exercise of constitutional rights and freedoms shall not be arbitrary and unfair, they shall be provided solely by the Constitution and the laws of Ukraine, pursue a legitimate goal, be substantiated by the public need to achieve this goal, they shall be proportionate and justified, in case of placing restrictions on a constitutional right or freedom the legislator is bound to introduce a legal regulation to ensure the optimum achievement of the legitimate goal along with the minimum interference with the exercise of this right or freedom and with no changes to the substantial meaning of this right. ${ }^{59}$

At the same time the CCU emphasized that:

though mental health precludes legally incompetent persons from the personal exercise of certain constitutional rights and freedoms, including the right to liberty, personal security, they cannot be completely deprived of these rights and freedoms, that is why the state is bound to establish effective legislative mechanisms and guarantees for their exercise to the maximum extent possible. [...] The basis for the Decision of the Constitutional Court of Ukraine is that freedom is one of the fundamental values proclaimed by the effective constitutional democracy, the existence of individual freedom is one of the preconditions for his or her development and socialization. The right to freedom is an inherent and inalienable right of an individual, it provides for the choice of behaviour to ensure free and comprehensive development, independent actions in line with personal decisions and intents, setting priorities and doing everything that is not prohibited by the law, free and unimpeded movement across the territory of the state, the freedom to choose the place of residence, etc. The right to freedom means that an individual is free of any external interference in his or her activity, except for the restrictions imposed by the Constitution and the laws of Ukraine. ${ }^{60}$

It is important to note that in this Decision the CCU analyzed numerous international and European documents that, in particular, ensured the guarantees of freedom and personal security of a person with mental disability. It prompted the Court to arrive at the opinion that there is a need to exercise judicial control over the interference with the right to freedom and personal security of a person with mental disability when this person is admitted to a mental facility without his or her consent. The CCU states that the procedure established by the Law provides for admission of a legally incompetent person to a mental facility without this person's informed consent, by its nature and consequences it is a disproportionate restriction on a legally incompetent person's constitutional

59 Id.

60 Id. 
right to freedom and personal security, that is why it must be implemented with the compliance to the constitutional guarantees for the protection of individual rights and freedoms exclusively by the court's decision. ${ }^{61}$

Moreover, the operative part of the CCU's Decision recommended the Verkhovna Rada of Ukraine to immediately bring the provisions of the laws of Ukraine regarding the provision of mental health in compliance with this Decision. ${ }^{62}$

Thus, this Decision by the CCU adopted already after some partial reform and modernization of the change in the composition of Judges with the CCU, especially the arguments behind it, specified primarily in the reasoning part of the Decision, is essentially different from the arguments behind the previous decisions. The analyzed Decision was in fact hailed as one of the most progressive not only by the legal community but also by all the bodies of state government, it has made a significant boost to the authority and the growing role of the CCU in the formation and development of law.

It must be noted, however, that this Decision had three dissenting opinions by the CCU Judges. CCU Judge I.D. Slidenko made the following comment in his dissenting opinion:

[...] The merits of this case under the formulated 'specifically legal' way in the Petition provided for the change of one constitutional model with another, the one typical of the Romano-Germanic law is replaced with another, that of the common law. And this is exactly the error in this Decision, because one constitutional model cannot be replaced with another one because of subjective factors - $[\ldots]$ inadequate perception of the constitutional conflict model, the specific understanding of means and capacities of constitutional review, etc. It is evident that the change of one model of constitutional relations in cases when it is reasonable, expedient or necessary, is the domain of the legislature or of the direct democracy. Another evident observation is that the Constitutional Court of Ukraine is neither a legislature, nor any of the known forms of the direct democracy ('emphasis added'). ${ }^{63}$

In addition, the Judge also mentions that in the reasoning part of the Decision, where the CCU sets a specific procedure to implement the Decision, the $C C U$ was outside of its powers, it was "independently regulating public relations in a method, that is provided by neither the Constitution of Ukraine, nor the laws

61 Id.

62 Id.

63 Dissenting opinion of CCU Judge Slidenko I. D. on the Decision of the Constitutional Court of Ukraine of 1 June 2016 no. 2-rp/2016. [online]. Available at: <https://zakon.rada. gov.ua/laws/show/nba2d710-16> Accessed: 19.10.2019. 
of Ukraine" ('emphasis added') ${ }^{64}$, in this way the court stepped outside of its competence and, consequently, entered into law-making. "At present the mechanism of admission to mental facilities, that used to be specified by the Article of the Law, is regulated exclusively by the Decision. Thus, the Constitutional Court of Ukraine took in its own hands the regulation of public relations" ('emphasis added'). ${ }^{65}$

The CCU declared unconstitutional not a specific norm but a certain approach in accordance with certain subjective views of the matter by the subject of the right to Petition [...]. It is evident that in this case the Constitutional Court of Ukraine has once again stepped outside of the scope of its powers by performing the legislature's function ('emphasis added') ${ }^{66}$

In the dissenting opinion CCU Judge N.K. Shaptala also stated that in this Decision the CCU used 'judicial activism' ('emphasis added'). ${ }^{67}$

However, on 14 November 2017 the Parliament passed the Law 'On Amendments to Certain Legislative Acts of Ukraine on Providing Psychiatric Aid'68 (Law no. 2205), that made changes to Paragraph 1, Article 13 of the Law that actually contradict the previous legal position of the CCU spelled out in its Decision of 1 June $2016 .{ }^{69}$ So, the analysis of the provisions in the Law makes it possible to claim that a legally incompetent person, whose health condition prevents him or her from voicing a request or providing an informed written consent, is admitted to a mental facility pursuant to the decision (consent), given by guardianship and custody bodies, i.e. without the court's decision. ${ }^{70}$

Hence, in the subsequent Decision the CCU emphasized that the laws, other legal acts or certain provisions thereof, found unconstitutional, shall not be adopted in a similar version, because the decisions of the Constitutional Court of Ukraine are "binding on the whole territory of Ukraine, they are final and may not be appealed"71; "by passing legal regulations with the same fault the

64 Id.

65 Id.

66 Id.

67 Dissenting opinion of CCU Judge Shaptala N. K. on the Decision of the Constitutional Court of Ukraine of 1 June 2016 no. 2-rp/2016. [online]. Available at: <https://zakon.rada. gov.ua/laws/show/en/nca2d710-16\#n3> Accessed: 19.10.2019.

68 Закон України 'Про внесення змін до деяких законодавчих актів України щодо надання психіатричної допомоги’ від 14 листопада 2017 р. № 2205-VIII. Відомості Верховної Ради (ВВР), 2017, № 51-52, ст.448, ч. 1, ст. 13 (The Law of Ukraine 'On Amendments to Certain Legislative Acts of Ukraine on Providing Psychiatric Aid' no. 2205-VIII of 14 November 2017. Bulletin of the Verkhovna Rada of Ukraine, 2017, no. 51-52, st.448, Art. 13, Para. 1). [online]. Available at: <https://zakon.rada.gov.ua/laws/show/2205-19> Accessed: 19.10.2019.

69 Decision of the Constitutional Court of Ukraine of 1 June 2016 no. 2-rp/2016.

70 The Law of Ukraine 'On Amendments to Certain Legislative Acts of Ukraine on Providing Psychiatric Aid' of 14 November 2017, Art. 13 Para. 1.

71 Decision of the Constitutional Court of Ukraine of 20 December 2018 no. 13-r/2018. [online]. Available at: <https://zakon.rada.gov.ua/laws/show/v013p710-18\#n2> Accessed: 
Verkhovna Rada of Ukraine violated the requirement of Paragraph 2, Article 8 of the Fundamental Law of Ukraine under which laws and other normative legal acts are adopted on the basis of the Constitution of Ukraine and shall conform to it" ${ }^{72}$ The CCU underscored that under the Constitution of Ukraine the decisions by the Constitutional Court of Ukraine:

are binding and final, after their publication the legal positions of the Constitutional Court of Ukraine spelled out in these decisions and being in the normative unity with the provisions of the Constitution of Ukraine interpreted in these decisions, turn into direct regulators of public relations, they particularly define the essence and the scope of constitutional rights and freedoms ('emphasis added'). ${ }^{73}$

Thus, the CCU arrived at the opinion that the provisions of Paragraph 1, Article 13 of the Law 'On Psychiatric Aid'74 contradict Paragraph 2, Article 8 of the Constitution of Ukraine since they introduce a legal regulation of public relations that was unconstitutional. Thus, the Constitutional Court of Ukraine in its Decision of 20 December 2018, upheld the legal position made by the Court in the Decision of 1 June $2016^{75}$, and ruled that:

until there is legal regulation on the issue of judicial control over the procedure of admitting a legally incompetent person to a mental facility while this person's health condition does not allow him or her to voice a request or provide an informed written consent, such an admission to a mental facility is possible only upon a court's decision. ${ }^{76}$

2.3 Where do the 'law-making' elements appear most often in terms of the content of the constitutional court's ruling?

As a rule, the elements of the CCU's law-making are present in the reasoning and operative parts of the decision. Namely, the reasoning part of the Decision of the CCU of 29 December 1999, no. 11-rp/99 (the case involving death penalty) ${ }^{77}$ the CCU stated:

The key point in the definition of the human right to life under the Constitution of Ukraine is the provision under which this right is inherent

19.10.2019.

72 Id.

73 Id.

74 Закон України 'Про психіатричну допомогу' від 22 лютого 2000 р. № 1489-III. Відомості Верховної Ради України (ВВР), 2000, № 19, ст.143, ч. 1, ст. 13 (The Law of Ukraine 'On Psychiatric Aid' no. 1489-VIII of 22 February 2000. Bulletin of the Verkhovna Rada of Ukraine, 2000, no. 19, st.143, Art. 13, Para. 1). [online]. Available at: <https:// zakon.rada.gov.ua/laws/show/1489-14> Accessed: 19.10.2019.

75 Decision of the Constitutional Court of Ukraine of 1 June 2016 no. 2-rp/2016.

76 Decision of the Constitutional Court of Ukraine of 20 December 2018 no. 13-r/2018.

77 Decision of the Constitutional Court of Ukraine of 29 December 1999 no. 11-rp/99. 
(Paragraph 1, Article 27), inalienable and inviolable (Article 21). A person has the right to life from birth and it is protected by the state. The Constitution of Ukraine proclaims that the constitutional rights and freedoms are guaranteed and shall not be abolished (Paragraph 2, Article 22), and that the Constitution of Ukraine shall not be amended, if the amendments foresee the abolition or restriction of human and citizens' rights and freedoms (Paragraph 1, Article 157). The content and scope of existing rights and freedoms shall not be diminished, including the inherent human right to life, in the adoption of new laws or in the amendment of applicable laws (Paragraph 3, Article 22). Thus, the content of the provisions specified in Paragraph 2, Article 22 of the Constitution of Ukraine establish, on the one hand, the duty of the state to guarantee constitutional rights and freedoms, primarily the individual right to life, on the other hand, the same duty to refrain from adopting any acts that would entail the abolition of constitutional rights and freedoms, i.e. the individual right to life. With the guide of the provisions in Paragraph 2, Article 8 of the Constitution of Ukraine, the norm specified in Article 22 of the Constitution should be taken into account during the adoption of laws and other normative and legal acts that regulate the respective public relations. Taking the human life by the state as the result of a death penalty as a type of punishment, even within the provisions specified by the law, is a derogation of the integral human right to life, it contradicts the Constitution of Ukraine [...]. The guarantee for any individual's inalienable right to life as well as any other human and civil rights and freedoms in Ukraine are based on the maxim that: exceptions regarding the individual and civil rights and freedoms are established solely by the Constitution of Ukraine and not the laws or any normative acts ('emphasis added'). ${ }^{78}$

Thus, the operative part of the Decision by the CCU found unconstitutional the provisions of the Criminal Code of Ukraine that provided for death penalty as a type of punishment and decreed that these provisions lose their effect from the day of the adoption by the Court of the present Decision. ${ }^{79}$

\subsubsection{Case on compliance with the procedure for amending the Constitution of Ukraine}

In its turn the reasoning part of the Decision by CCU of 30 September 2010, no. $20-\mathrm{rp} / 2010^{80}$ states that:

the opinion of the Constitutional Court of Ukraine is based on the situation in which finding the Law no. 2222 unconstitutional because of the procedural violations during its consideration and adoption means the

78 Id.

79 Id.

80 Decision of the Constitutional Court of Ukraine of 30 September 2010 no. 20-rp/2010. 
revival of the previous version of the norms spelled out by the Constitution of Ukraine prior to their change, amendment and exclusion by the Law no. 2222. It ensures the stability of the constitutional order in Ukraine, guarantees constitutional human and civil rights and freedoms, secures the integrity, inviolability and continuity of the Constitution of Ukraine, its supremacy as the Fundamental Law of the land across the whole territory of Ukraine. ${ }^{81}$

Thus, the operative part of the Decision by the CCU charged the bodies of state government with the duty to immediately implement the present Decision in part of bringing normative and legal acts in compliance with the Constitution of Ukraine of 28 June 1996, in the version prior to the amendments introduced by the Law of Ukraine 'On Introducing Amendments to the Constitution of Ukraine' of 8 December 2004, no. 2222-IV. ${ }^{82}$

\subsubsection{Case on the punishment of public officials for illicit enrichment}

In one of the most debated Decisions by the CCU, the one of 26 February 2019 no. 1-r/2019 (the case involving the punishment of public officials for illicit enrichment), the CCU stated in the reasoning part of the Decision that:

the principle of in dubio pro reo, meaning that all doubts of the person's guilt in the process of assessing the evidence should be resolved in favour of this person, constitutes an element of the principle of presumption of innocence. The presumption of innocence implies that the burden of proof lies with the state. [...] The definition of illicit enrichment in the law presents it as a crime on the condition that the accused fails to comply with the duty of collecting evidence supporting the legitimacy of acquiring assets to the required extent, thus making it possible for the shift of this duty and the burden of proof from the prosecution (the state) to the defence (the suspect or the accused), it is unacceptable with the view of the constitutional principle of innocence because this practice violates the norms spelled out in Paragraph 2, Article 62 of the Constitution of Ukraine reading that no one is obliged to prove his or her innocence of committing a crime, i.e. the right of an individual not to prove his or her innocence of committing a crime. ${ }^{83}$

Hence, the CCU arrived at the opinion that the present provision of the Criminal Code of Ukraine does not meet the requirement for legal certainty as an element of the constitutional principle of the rule of law, since the disposition of this norm is not sufficiently clear and allows for ambiguous understanding, interpretation and application. In addition, the Article in question is not in conformity with the con-

81 Id.

82 Id.

83 Decision of the Constitutional Court of Ukraine of 26 February 2019 no. 1-r/2019. [online]. Available at: <https://zakon.rada.gov.ua/laws/show/v001p710-19> Accessed: 19.10.2019. 
stitutional principle of the presumption of innocence and the constitutional prescription that a person shall not bear responsibility for refusing to testify or to explain anything about himself or herself, members of his or her family or close relatives (Paragraph 1, Article 63 of the Constitution of Ukraine) ${ }^{84}$

With this guide the Constitutional Court of Ukraine stated in the operative part of this Decision that it has found the provisions of the Criminal Code of Ukraine on illicit enrichment to be non-conforming to the Constitution of Ukraine and thus they lose their effect from the day of the adoption by the Court of the respective Decision. ${ }^{85}$

2.4 Is there any influence of law-making activity of the constitutional courts of other states on the practice of the CCU?

It is not common for the CCU to refer in its decisions to the practice of foreign constitutional courts for a number of objective reasons. One of them is associated with the legal nature and judicial effect of its decisions. Some scholars believe that, since under the Constitution of Ukraine the decisions by the Constitutional Court of Ukraine are binding on the whole territory of Ukraine, "it is legally unacceptable to refer in these decisions to legal sources that are not binding on our state". ${ }^{86}$ Another reason lies in the affiliation of Ukrainian legal system with the Romano-Germanic legal family where the case law (court practice) is historically not that much influential compared to the states within the AngloSaxon legal family (the common law system) ${ }^{87}$ At the same time while deciding on cases the CCU takes an indirect account of foreign practice in constitutional proceedings that pertain to certain matters. References to legal positions of foreign constitutional courts are cited primarily in the dissenting opinions of the CCU Judges.

For instance, in the dissenting opinion on the CCU's Decision in the case of 26 February 2019, no. 1-r/201988 (the case of finding unconstitutional Article $368^{-2}$ of the Criminal Code of Ukraine on the crime of 'illicit enrichment') CCU Judge V.V. Lemak emphasized that:

the methods underlying the interpretation of law, if we take into account the experience of foreign constitutional courts, allow for the situation in which the availability of different interpretations of a certain provision of the law where one confirms with constitutional principles, while the other does not, shall not give grounds for the revocation of this provision

84 Id.

85 Id.

86 National Report of the Constitutional Court of Ukraine. In Proceedings from XVI Congress of the Conference of European Constitutional Courts 'Cooperation between Constitutional Courts in Europe - Framework Conditions and Existing Prospects'. Kyiv, 2013, p. 25.

87 Id.

88 Decision of the Constitutional Court of Ukraine of 26 February 2019 no. 1-r/2019. 
(constitution-conform interpretation) (see also the Decision of the Constitutional Court of the Czech Republic of 26 March 1996, Pl.US 48/95). The Court found the norm unconstitutional even without trying to interpret it. ${ }^{89}$

Moreover, in the dissenting opinion on the CCU's Decision in the case of 26 February 2019, No. 1-r/2019 (the case involving illicit enrichment) ${ }^{90}$ CCU Judge S.V. Shevchuk refers to the practice of the Supreme Courts in the USA and Canada. "I am in full support of the Court's position because it actually implements into the constitutional matter of Ukraine a known standard of the void for vagueness doctrine that is common in the practice of the Supreme Court of the United States of America" (italic and bold emphasis in the original). ${ }^{91}$

At the same time the CCU's decisions have numerous references to international sources of law, namely, the Universal Declaration of Human Rights, the European Convention for the Protection of Human Rights and Fundamental Freedoms, the European Social Charter of 1996 (while considering cases involving the protection of social rights, particularly the right to social security (Article $12)^{92}$, health care, social and medical assistance (Articles 11, 13) (33 $^{93}$ the right to housing (Article 31) $)^{94}$ and others.

For example, the European Charter with regard to the Law 'On the Judiciary and Status of Judges' of 10 July 1998, was used in the aspects of the liability $(\text { Clause } 5.1)^{95}$, remuneration and social welfare of judges (Clause 6). ${ }^{96}$

So, while considering cases that involve the question regarding the independence of judges, the CCU referred to the Recommendation No. (94) 12 by the Council of Europe Committee of Ministers 'On the Independence, Efficiency

89 Dissenting opinion of CCU Judge Lemak V. V. on the Decision of the Constitutional Court of Ukraine of 26 February 2019 no. 1-r/2019. [online]. Available at: <https://zakon.rada. gov.ua/laws/show/nd01d710-19\#n56> Accessed: 19.10.2019.

90 Decision of the Constitutional Court of Ukraine of 26 February 2019 no. 1-r/2019.

91 Dissenting opinion of CCU Judge Shevchuk S.V. on the Decision of the Constitutional Court of Ukraine of 26 February 2019 no. 1-r/2019. [online]. Available at: <https://zakon. rada.gov.ua/laws/show/nh01d710-19\#n2> Accessed: 19.10.2019.

92 Decision of the Constitutional Court of Ukraine of 8 October 2008 no. 20-rp/2008. [online]. Available at: <https://zakon.rada.gov.ua/laws/show/v020p710-08> Accessed: 19.10.2019.

93 Decision of the Constitutional Court of Ukraine of 29 May 2002 no. 10-rp/2002. [online]. Available at: <https://zakon.rada.gov.ua/laws/show/v010p710-02 > Accessed: 19.10.2019.

94 Decision of the Constitutional Court of Ukraine of 13 March 2012 no. 5-rp/2012. [online]. Available at: <https://zakon.rada.gov.ua/laws/show/v005p710-12> Accessed: 19.10.2019.

95 Decision of the Constitutional Court of Ukraine of 11 March 2011 no. 2-rp/2011. [online]. Available at: <https://zakon.rada.gov.ua/laws/show/v002p710-11> Accessed: 19.10.2019.

96 Decision of the Constitutional Court of Ukraine of 14 December 2011 no. 18-rp/2011. [online]. Available at: <https://zakon.rada.gov.ua/laws/show/v018p710-11> Accessed: 19.10.2019. 
and Role of Judges' of 13 October $1994,{ }^{97}$ as well as the Recommendation by the Council of Europe Committee of Ministers to Its Member States Regarding Judges: Independence, Efficiency and Responsibilities of 17 November 2010, No. $12(2010)^{98}$, etc.

\subsection{Filling in the gaps in the laws}

The way in which the CCU uses elements of law-making can be traced, among others, to the situations when there are gaps in legal regulation of certain areas of public relations. At the same time it must be noted that from the legal standpoint it is not the CCU's main task to identify and study any gaps in the legislation. In addition, the Constitution of Ukraine does not provide for any specific procedure for studying such gaps. While the analysis of the Constitutional provisions and the Law 'On the Constitutional Court of Ukraine' shows that the CCU has these powers expressis verbis. In addition, the CCU identifies this capacity to study gaps in the legislation in its own acts: declaring the need for legislative regulation of certain legal relations; refusal to interpret legislative gaps that could be tantamount to interference within the realm of the legislative branch of government. ${ }^{99}$

The Constitutional Court of Ukraine considers cases exclusively on the initiative of the subjects of the right to constitutional petition/appeal. Under the Constitution of Ukraine subjects of the right to constitutional petitions include: the President of Ukraine, a group of at least forty-five People's Deputies of Ukraine, the Supreme Court, the Commissioner of the Verkhovna Rada of Ukraine for Human Rights, and the Verkhovna Rada of the Autonomous Republic of Crimea. ${ }^{100}$ At the same time, in cases when the CCU identifies a legislative gap, the Court states that the issues raised in the constitutional petition, constitutional appeal, or constitutional complaint fall beyond the Court's competence, ${ }^{101}$ as a rule it simply identifies the presence of a gap in legislation and refers its legal position to the respective law-making body and refuses to initiate constitutional proceedings in the case. ${ }^{102}$

97 Decision of the Constitutional Court of Ukraine of 11 March 2010 no. 7-rp/2010. [online]. Available at: <https://zakon.rada.gov.ua/laws/show/v007p710-10> Accessed: 19.10.2019.

98 Decision of the Constitutional Court of Ukraine of 14 December 2011 no. 18-rp/2011.

99 Interpretation of the jurisdiction of the constitutional court to investigate and assess the constitutionality of legal gaps in the constitutional jurisprudence. In the National Report of the Constitutional Court of Ukraine 'On the Problem of Legislative Gaps in the Constitutional Jurisprudence', p. 8.

100 The Law of Ukraine 'On the Constitutional Court of Ukraine' of 13 July 2017, Art. 52, Para. 1.

101 Id., Art. 62.

102 Refusal by the constitutional court to investigate and assess legal gaps. In the National Report of the Constitutional Court of Ukraine 'On the Problem of Legislative Gaps in the Constitutional Jurisprudence', p. 11. 
Hence the gap in legislation is specified in the reasoning part of the CCU act and, as a rule, it also states that the filling in of any legislative gaps belongs to the competence of the Verkhovna Rada of Ukraine. In addition, under Article 51, Paragraph 4 of the Law of Ukraine 'On the Constitutional Court of Ukraine', the constitutional petition regarding the official interpretation of the Constitution of Ukraine shall specify particular provisions of the Constitution of Ukraine which require official interpretation and substantiation of the reasons that have necessitated interpretation. ${ }^{103}$ It means that the subjects of the right to constitutional petition and appeal cannot raise a single issue regarding a legislative gap, since the decision on this issue falls beyond the competence of the Court. ${ }^{104}$

At the same time, the CCU can identify the presence of gaps in the legal regulation. Still the identification of such gaps does not constitute the Court's main function. The CCU's National report states:

The Constitutional Court of Ukraine cannot fill in the gaps in legislation through the power of official interpretation. Being the body that applies the law, the Constitutional Court of Ukraine can serve as a 'negative' legislator by declaring unconstitutional acts or some of their provisions. [...] the Constitutional Court of Ukraine ensures the supremacy of the Constitution of Ukraine as the Fundamental Law of the land, that is why the lawmaking bodies shall be guided, in addition to the Constitutional norms and universal legal principles, by the decisions and legal positions of the Constitutional Court of Ukraine, that indirectly formulate certain criteria for new regulation of public relations ('emphasis added'). ${ }^{105}$

In its practice the CCU has also formulated the consequences for the identification by the CCU of any legislative gaps. Namely, the Decision of 25 March 1998 no. 3-rp in the case involving the official interpretation of the Law of Ukraine 'On Elections of People's Deputies of Ukraine' the CCU stated that

filling in the gaps in the laws whose certain provisions the Constitutional Court of Ukraine found unconstitutional falls outside of its competence. Under Article 6 of the Constitution of Ukraine the state power in Ukraine is exercised on the principles of its division into legislative, executive and judicial power. With this guide and in accordance with the Paragraph 2, Article 19 of the Constitution of Ukraine the prerogative of addressing these issues lies with the legislative body, i.e. the Verkhovna Rada of Ukraine. ${ }^{106}$

103 The Law of Ukraine 'On the Constitutional Court of Ukraine' of 13 July 2017, Art. 51, Para. 4. 104 Legislative omission as an object of investigation by the Constitutional Court. In the National Report of the Constitutional Court of Ukraine 'On the Problem of Legislative Gaps in the Constitutional Jurisprudence', p. 9.

105 Id., p. 21.

106 Decision of the Constitutional Court of Ukraine of 25 March 1998 no. 3-rp/98. The Official Bulletin of Ukraine, 1998, no. 23, p. 110, Art. 852, Act Code 5486/1998. [online]. Available 
The reasoning of the CCU to reject the initiation of the constitutional proceedings is the following: "[...] the streamlining of certain specific state and official relations, eliminating inconsistencies and filling in the gaps in the applicable laws fall outside of the competence of the Constitutional Court of Ukraine" (Ruling of the CCU of 10 November 1998 no. 41-y on the rejection to initiate constitutional proceedings in the case involving the constitutional petition of the Central Election Commission on the official interpretation of Paragraph 1, Article 9 of the Law of Ukraine 'On Civil Service'); 107 " [...] The elimination of legal collisions and filling in the gaps in legislative acts, is the exclusive competence of the Verkhovna Rada of Ukraine as the sole body of legislative power in Ukraine as per Article 85 of the Constitution of Ukraine" (Ruling of the CCU of 15 January 2004 no. 1-y on the rejection to initiate constitutional proceedings in the case involving the constitutional petition made by 50 People's Deputies of Ukraine concerning the constitutionality of the provisions of Article 2 of the Law of Ukraine 'On the Procedure of Allocation of Land Plots in Kind (in Places) to the Owners of Land Portions' and the official interpretation of Paragraph 3, Article 82 of the Land Code of Ukraine); ${ }^{108}$

[...] it is the Verkhovna Rada of Ukraine that determines the procedure for the vote by the People's Deputies of Ukraine to appoint to and dismiss from office the Human Rights Ombudsperson of the Verkhovna Rada of Ukraine, that eliminates collisions and fills in the gaps in the laws regarding this issue pursuant to the legislative order, on the grounds, within the scope of powers and pursuant to the regulation spelled out in the Constitution and the laws of Ukraine [...], and it falls outside of the competence of the Constitutional Court of Ukraine. ${ }^{109}$

On the other hand, in some of its decisions the CCU pointed out the need to regulate the relations that were 'damaged' in the course of finding a legal normative act unconstitutional. Namely, the Decision of 29 December 1999, no. 11-rp/1999 in the case of death penalty the CCU compelled the Verkhovna Rada of Ukraine to bring the Criminal Code of Ukraine up to standard with this CCU's Decision (Paragraph 3 of the operative part of the Decision). ${ }^{110}$ Similar wording was used in the CCU's Decision of 9 July 2002 no. 15-rp/2002 in the case involving the pretrial settlement of disputes, ${ }^{111}$ as well as in the Decision of

at: <https://zakon.rada.gov.ua/laws/show/v003p710-98> Accessed: 19.10.2019.

107 Ruling of the Constitutional Court of Ukraine of 10 July 1998 no. 41-y/98. [online]. Available at: <https://zakon.rada.gov.ua/laws/show/v041u710-98> Accessed: 19.10.2019.

108 Ruling of the Constitutional Court of Ukraine of 15 January 2004 no. 1-y/2004. [online]. Available at: <https://zakon.rada.gov.ua/laws/show/v001u710-04> Accessed: 19.10.2019.

109 Ruling of the Constitutional Court of Ukraine of 29 August 2018 no. 50-y/2018. [online]. Available at: <https://zakon.rada.gov.ua/laws/show/v050u710-18> Accessed: 19.10.2019.

110 Decision of the Constitutional Court of Ukraine of 29 December 1999 no. 11-rp/99.

111 Decision of the Constitutional Court of Ukraine of 9 July 2002 no. 15-rp/2002. [online]. Available at: <https://zakon.rada.gov.ua/laws/show/v015p710-02> Accessed: 19.10.2019. 
2 November 2004 no. 15-rp/2004 in the case involving the courts' imposition of more lenient sentences. ${ }^{112}$

In addition, under Article 97 of the Law of Ukraine 'On the Constitutional Court of Ukraine' the CCU in its decision or opinion may establish the procedure for and terms of the execution thereof and oblige relevant government authorities to provide monitoring of the execution of such decision or compliance with such opinion. The Court may demand a written confirmation of the execution of a decision or compliance with an opinion from the relevant authorities. ${ }^{113}$ Namely, the Decision of 14 December 2000, no. 15-rp/2000 in the case involving the procedure for the execution of its decisions CCU states that

[...] irrespective of the presence or absence of instructions by the Constitutional Court of Ukraine in its decisions or opinions regarding the execution thereof, the respective laws, other legal acts or some of their provisions, found unconstitutional as per these decisions, shall not be applied and shall be deemed void from the day of the adoption by the Court of a decision declaring their unconstitutionality (Paragraphs 5, 6 in Clause 4 of the operative part of the Decision). ${ }^{114}$

In the Decision of 20 June 2007, no. 5-rp/2007 in the case involving creditors of enterprises of communal ownership the CCU stated that "the positive duty of the legislator is to fill in the legislative gaps in Article 40 of the Law to ensure the accurate application of the disputed position by the courts of law" (Clause 5 of the reasoning part). ${ }^{115}$ It must be noted in this respect that the Verkhovna Rada's Rules of Procedure ${ }^{116}$ do not provide for considering issues involving the implementation of the CCU's decisions. The Parliament's duty with regard to the CCU is to implement the decisions of the Constitutional Court of Ukraine. ${ }^{117}$

112 Decision of the Constitutional Court of Ukraine of 2 November 2004 no. 15-rp/2004. [online]. Available at: <https://zakon.rada.gov.ua/laws/show/v015p710-04> Accessed: 19.10.2019.

113 The Law of Ukraine 'On the Constitutional Court of Ukraine' No. 2136-VIII of 13 July 2017, Art. 97.

114 Decision of the Constitutional Court of Ukraine of 14 December 2000 no. 15-rp/2000. [online]. Available at: <https://zakon.rada.gov.ua/laws/show/v015p710-00> Accessed: 19.10.2019.

115 Decision of the Constitutional Court of Ukraine of 20 June 2007 no. 5-rp/2007. [online]. Available at: <https://zakon.rada.gov.ua/laws/show/v005p710-07> Accessed: 19.10.2019.

116 Закон України ‘Про Регламент Верховної Ради України’ від 10 лютого 2010 р. № 1861VI. Відомості Верховної Ради України (ВВР), 2010, № 14-15, № 16-17, ст.133 (The Law of Ukraine 'On the Rules of Procedure of the Verkhovna Rada of Ukraine' of 10 November 2010 no. 1861-VI. Bulletin of the Verkhovna Rada of Ukraine, 2010, no. 14-15, no. 16-17, st.133). [online]. Available at: $<$ https://zakon.rada.gov.ua/laws/show/1861-17?find=1\&tex $\mathrm{t}=\% \mathrm{CA} \% \mathrm{EE} \% \mathrm{ED} \% \mathrm{~F} 1 \% \mathrm{~F} 2 \% \mathrm{E} 8 \% \mathrm{~F} 2 \% \mathrm{~F} 3 \% \mathrm{~F} 6 \% \mathrm{~B} 3 \% \mathrm{E} 9 \% \mathrm{ED} \% \mathrm{E} 8 \% \mathrm{E} 9+\% \mathrm{~F} 1 \% \mathrm{~F} 3 \% \mathrm{E} 4$ w11> Accessed: 19.10.2019.

117 Consequences of the Statement of the Existence of Legislative Omission in Constitutional Court Decisions. Duties arising to the Legislator. In the National Report of the Constitu- 


\section{Approaches to constitutional interpretation applied by the $\mathrm{CCU}$}

\subsection{Making a 'choice' between the results of using different methods of interpre- tation}

The CCU's decisions regarding the official interpretation of the Constitution in their descriptive and reasoning parts consist of some references to the methods of interpreting the law that were applied, namely: systematic, logical, grammatical, functional, comparative, historical, teleological. Usually, the CCU uses a combination of these methods with the view of the comprehensive analysis and study of the provisions to be interpreted. The use of these methods and their combination is at the discretion of the CCU Judges, and in some of the CCU decisions, where a dissenting opinion is provided, the Judges state their own considerations on the use of certain interpretation methods that laid the ground for their own vision of the official interpretation for certain provisions of the Constitution of Ukraine. ${ }^{118}$

It is quite common for the CCU to use the systematic analysis method to analyze a legal act along with the analysis into the practice of using this act by government bodies. The method of logical interpretation used by the CCU provides for the use of formal logic to identify the overall meaning of a norm and eliminate certain inconsistencies. Teleological interpretation by the CCU is worth a special mention. This type of interpretation is quite effective while dealing with cases that involve competence issues. At the same time, the CCU rarely reserves to the use of a comparative method that implies the analysis into the practice of Constitutional or Supreme Courts of foreign states. ${ }^{119}$

It can be stated that it is the systematic method for the interpretation of legal norms that is the most common in the legal interpretation practice of the CCU, as compared to other methods of interpreting legal norms, the primary reason for that is the systemic feature of the law and legislation. At the same time all the CCU's official interpretation acts that use the systematic interpretation method can be divided into those that in their names bear the reference to the use of the systematic interpretation that constitutes the foundation for the official interpretation, and those that do not have any reference to the use of the systematic

tional Court of Ukraine: 'On the Problem of Legislative Gaps in the Constitutional Jurisprudence', pp. 18-19.

118 Котенко М. В. Роль системного тлумачення в правоінтерпретаційній діяльності Конституційного Суду України. Часопис Київського університету права, 2015, № 2, c. 61-67 (KOTENKO, Mykola. Systematic interpretation and its role in the law-interpretational activities of the Constitutional Court of Ukraine. Scientific Journal "Chronicles of KUL", 2015, no. 2, pp. 61-67).

119 The Methodology of Revelation of Legislative Omission. In the National Report of the Constitutional Court of Ukraine 'On the Problem of Legislative Gaps in the Constitutional Jurisprudence', p. 15. 
interpretation method in their names, while the text of the decision itself has a mention that this method was the main one or among the main ones. ${ }^{120}$

Analysis of the CCU's rulings for the period from 1997 (the year when the 'The Bulletin of the Constitutional Court of Ukraine' was established as an official publication of the Court) until 2015 allowed identifying over this period of time the changes in the content of the Court's rulings on the rejection to initiate constitutional proceedings. While in the beginning of the 1990s and the early 2000s the main focus was made on the descriptive part of the circumstances of the case, nowadays the text of the rulings is more focused on the legal linguistic, logical, systematic interpretation of legal norms, it is more in line with the main principles of legal hermeneutics and makes these legal texts more compelling and objective. ${ }^{121}$

In its decisions the CCU frequently refers to the legislator's intentions emphasizing the need for their accurate establishment. ${ }^{122}$ According to O. Denkovych, the CCU's practice often features the use of the following special means to reflect the legislator's intent: transcripts of the sessions of the Verkhovna Rada of Ukraine in which a certain legal and normative act was passed, drafts of such acts, records of their consideration, etc. ${ }^{123}$ This approach was relatively common in the Soviet legal doctrine (the so-called 'objective legal interpretation' theor ${ }^{124}$, static interpretation theory, in the USA - 'originalism'). Hence it was an accepted view that the dynamic (objective, evolutive, 'creative') interpretation is a type of law-making 'disguised' as interpretation, that is why it must be rejected within the context of the law-governed state. ${ }^{125}$ In this respect the use of the dynamic ('non-originalism', the 'living' Constitution doctrine) interpretation is not currently common in Ukraine, however, there are some recent attempts to substantiate its necessity and occasional practical use.

120 Id.

121 Топчій, В. Офіційне тлумачення конституційних норм щодо прав людини у парадигмі юридичної герменевтики. Публічне право, 2016, № 1 (21), с. 276-283 (ТОРCHII, Vasyl. The Official Interpretation of the Constitutional Provisions of Human Rights in the Paradigm of Legal Hermeneutics. Public Law, 2016, no. 1 (21), pp. 276-283).

122 Decision of the Constitutional Court of Ukraine of 25 October 2000 no. 12-rp/2000. [online]. Available at:<https://zakon.rada.gov.ua/laws/show/v012p710-00> Accessed: 19.10.2019.

123 Денькович О. Об'єкт та предмет тлумачення Конституційним Судом України в кримінальному праві. Вісник Львівського університету. Серія юридична, 2011, Вип. 52, c. 312-313 (DENKOVYCH, Olha. Object and Subject in the Interpretations Made by the Constitutional Court of Ukraine in the Criminal Law. Visnyk of the Lviv University. Series Law, 2011, vol. 52, pp. 312-313).

124 SAVIGNY, Friedrich Karl von. System des heutigen Römischen Rechts. Berlin: Veit und Comp., 1840, p. 6.

125 Гончаров В. Від старої теорії тлумачення до нової: основні виклики та рішення. Філософія права і загальна теорія права, 2014, № 1-2, с. 53-69 (HONCHAROV, Volodymyr. From the Old to the New Theory of Interpretation: the Main Challenges and Solutions. Philosophy of Law and the General Theory of Law, 2014, no. 1-2, pp. 53-69). 
V. Honcharov is of extremely criticizing opinion on the national interpretation theory and underscores that "the existing state of affairs leads to a certain burden of the Soviet legal sciences over Ukraine's contemporary interpretation doctrine" ${ }^{126}$ The author assumes that the lack of comprehensive progressive research on interpretation theory within the national legal doctrine is one of the factors why the CCU still continues to "use clearly outdated interpretation methodology, which can be traced in the following legal positions made by the Court: 'The official interpretation is the operation of the competent body of the state government to ascertain and clarify the legislator's intent materialized in the legal norm' (to understand and clarify the meaning of the legal norms aiming to ensure their most accurate implementation)". ${ }^{127}$

\subsection{The development and dynamic interpretation of the law}

The analysis into the laws of Ukraine and, primarily, the Constitution of Ukraine and the new Law of Ukraine 'On the Constitutional Court of Ukraine', will clearly show that the CCU is not granted with competence to create norms, i.e. de jure it has no powers to establish legal norms. But at the same time the functions, the powers, and most importantly, the practice of the Court will demonstrate the signs of its 'law-making' activity. In this context it is important to look at Article 92 ('Legal Position of the Constitutional Court') of the abovementioned law. The article states that the Court outlines its legal position in the reasoning and/or operative part of a decision or an opinion. The Court's legal position may be set forth in the Court's rulings, as delivered by the Senate or the Grand Chamber, which reject constitutional proceedings in a case or terminate constitutional proceedings in a case. It also states that

the Constitutional Court may develop and elaborate a legal position of the Court in its subsequent acts, change its legal position in the event of substantial change to normative regulations that the Court was guided by when expressing such position, or in the presence of objective grounds for the need to improve the protection of constitutional rights and freedoms, taking into account Ukraine's international obligations, subject to substantiation of such change in the Court's act ('emphasis added'). ${ }^{128}$

Thus, this novelty actually grants the CCU the right to change its own legal position, i.e. the already adopted decisions, in order to safeguard constitutional rights, and in this way the Court has the right to 'develop' the law through dynamic interpretation. Hence the opinions on the constitutionality of acts

126 Id.

127 Ruling of the Constitutional Court of Ukraine of 31 March 2010 no. 15-y/2010. [online]. Available at: <https://zakon.rada.gov.ua/laws/show/v015u710-10> Accessed: 19.10.2019.

128 The Law of Ukraine 'On the Constitutional Court of Ukraine' of 13 July 2017, Art. 92. 
(norms) of law, legal positions on regulating public relations, are the source of improving and developing certain branches of law. ${ }^{129}$

\subsubsection{Cases on social benefits provided by the state}

For instance, the CCU's decision on social benefits provided by the state can serve as an example of its dynamic interpretation. So, in the Decision of $20 \mathrm{March}$ 2002, the Court stated that

benefits, compensations and guarantees, specified by the applicable laws, supplement the main sources of subsistence and constitute the necessary element of the constitutional right to ensure the maintenance of the living standards, [...] any shrinking of the meaning and the scope of this right by means of passing new laws or amending the laws in force shall be prohibited as per Article 22 of the Constitution of Ukraine ('emphasis added'). ${ }^{130}$

Similar position was supported by the CCU in its Decision of 9 July 2007. The Court stated that

the citizens' rights to social protection as well as other social and economic rights can be limited, including the suspension of the laws (or certain provisions thereof), only in times of the martial law or the state of emergency for a limited period of time. [...] social benefits, compensations and guarantees that constitute an element of the constitutional right to social protection [...] are equally binding on state government bodies, bodies of local self-government and their officials. A failure by the state to deliver on the social commitments with regard to certain individuals puts these citizens in unequal conditions and undermines the principle of confidence in the state, which consequently undermines the principles of the social and law-governed state. [...] Thus, the Verkhovna Rada of Ukraine does not have the authority, while adopting the Law on the State Budget of Ukraine, to include with it any provisions on amending the applicable laws, suspend any laws of Ukraine and/or change in any way the legal regulation of public relations specified by other laws of Ukraine ('emphasis added'). ${ }^{131}$

However, in its Decision of 26 December 2011 the CCU changed its own position without giving sufficient substantiation for this change. The Court stated that:

Social and economic rights, specified by the laws, are not absolute. The state can change the mechanism of realization of these rights, i.e. because of the incapacity to secure their exercise financially through proportional redistribution of funds in order to preserve the balance of interests of the

129 SELIVANOV, Anatolii, STRYZHAK, Andrii, 2010, p. 113.

130 Decision of the Constitutional Court of Ukraine of 20 March 2002 no. 5-rp/2002. [online]. Available at: <https://zakon.rada.gov.ua/laws/show/v005p710-02 > Accessed: 19.10.2019.

131 Decision of the Constitutional Court of Ukraine of 9 July 2007 no. 6-rp/2007. [online]. Available at: <https://zakon.rada.gov.ua/laws/show/v0a6p710-07> Accessed: 19.10.2019. 
society in its entirety. In addition, such measures can be taken in the view of the necessity to prevent any actual threats to Ukraine's economic security. [...] Thus, the change in the mechanism of accrual of welfare payments and assistance should be guided by the criteria of proportionality and fairness and it is constitutionally acceptable within the limits beyond which the very meaning of the right to social protection is undermined ('emphasis added'). ${ }^{132}$

Thus, state social standards and state social guarantees may be established by both the laws of Ukraine and other normative and legal acts, namely the acts by the Cabinet of Ministers of Ukraine. ${ }^{133}$

So, in the Decision of 17 July 2018, the CCU again returned to its original position and emphasized that adopting the Law that introduces any restrictions on or termination of benefits, compensations and guarantees by the Law is a rejection by the state to deliver on the commitments provided by the Constitution of Ukraine, including those specifying the social protection of individuals affected by the Chernobyl nuclear disaster. Any restrictions on or termination of benefits for individuals specified by the law

without the equal substitute thereof or compensation constitute a violation of the state's commitments to ensure social protection for this category of people. In case of any regulatory changes the rights to benefits, compensations and guarantees acquired in this manner shall be preserved with the option for the implementation or introduction of equal or more beneficial conditions for social protection ('emphasis added'). ${ }^{134}$

Hence, the CCU stated in the operative part of the Decision that "additional pension benefits for the damaged health as well as the monthly compensation paid to the families that lost the provider as the result of the Chernobyl nuclear disaster shall be paid in full irrespective of the earnings, pension or any other income" ('emphasis added'). ${ }^{135}$

\subsubsection{Case on the permanent use of land parcels}

Some signs of the dynamic approach used in the Court's practice can be traced, for instance, in the Decision of the CCU of 22 September 2005, no. 5-rp/2005 in the case of the permanent use of land plots where the Court has found unconstitutional the provisions of Paragraph 6 Section X 'Transitional Provisions' of the Land Code of Ukraine "on the commitment to re-register the right to perma-

132 Decision of the Constitutional Court of Ukraine of 26 December 2011 no. 20-rp/2011. [online]. Available at: <https://zakon.rada.gov.ua/laws/show/v020p710-11> Accessed: 19.10.2019.

133 Id.

134 Decision of the Constitutional Court of Ukraine of 17 July 2018 no. 6-r/2018. [online]. Available at: <https://zakon.rada.gov.ua/laws/show/v006p710-18> Accessed: 19.10.2019. 135 Id. 
nent use of the land parcel into the right to property or the tenant right without the respective legal, organizational and financial support" ('emphasis added'). ${ }^{136}$ Thus, what the CCU actually stated was that the presence of the 'respective legal, organizational and financial support', i.e. under different conditions, would make this provision deemed as compliant with the Constitution of Ukraine (in the same version). ${ }^{137}$

\subsection{Doctrine of 'political question' in the practice of the CCU}

A separate mention should be made on the doctrine of 'political question' that is formulated in the constitutional practice of Ukraine. Namely, the Decision of 26 February 1998, no. 1-rp/1998 in the case involving the elections of the People's Deputies of Ukraine was the first time when the CCU applied and formulated the matter of 'political question'. The Constitutional Court arrived at the decision that

[...] the decision to deny the candidates running for a seat in Parliament on the list of candidates from political parties or election blocs of parties who failed to get past the four percent threshold of popular support the right to participate in the distribution of the mandates of the People's Deputy is the matter of political expediency to be regulated by the Verkhovna Rada of Ukraine (Paragraph 3, Clause 5 of the reasoning part of the Decision). ${ }^{138}$

The Doctrine of the 'political question' is also reflected in the CCU's Decision of 3 December 1998 no. 17-rp/1998 in the case involving the establishment of factions in the Verkhovna Rada of Ukraine. In this Decision the Court stated that "[...] establishment of the procedure regulating the organization and operation of parliamentary factions, decisions on their numbers, tasks, functions, goals, etc. are primarily matters of political expediency to be regulated by the Verkhovna Rada of Ukraine" (Paragraph 9, Clause 3 of the reasoning part of the Decision). ${ }^{139}$

\subsection{The future of evolutive and 'creative' interpretation of the CCU}

It must be underscored that recently the position of the Court on the dynamic interpretation of the law and the presence of its de facto law-making competence has been shifting towards a more extended interpretation of the CCU's powers on the development ('creation') of the law in the interpretation of the

136 Decision of the Constitutional Court of Ukraine of 22 September 2005 no. 5-rp/2005. [online]. Available at: $<$ https://zakon.rada.gov.ua/laws/show/v005p710-05 > Accessed: 19.10.2019. 137 Id.

138 Decision of the Constitutional Court of Ukraine of 26 February 1998 no. 1-rp/98. [online]. Available at: <https://zakon.rada.gov.ua/laws/show/v001p710-98> Accessed: 19.10.2019.

139 Decision of the Constitutional Court of Ukraine of 3 December 1998 no. 17-rp/98. [online]. Available at: <https://zakon.rada.gov.ua/laws/show/v017p710-98> Accessed: 19.10.2019. 
fundamental principles of the Constitution of Ukraine. It can be seen not only in public declarations but rather in the specific decisions passed by the Constitutional Court.

For example, during the working session of an international conference 'On the Role of the Constitutional Review Bodies in Ensuring the Rule of Law in Rule-Making and Law-Enforcement' held in Minsk (the Republic of Belarus) CCU Judge Serhii Vdovichenko in his report 'On the Principles of the Rule of Law in the Work of the Constitutional Court of Ukraine' provided an overview of certain trends and patterns in the development of the constitutional justice system in Ukraine for the past 20 years. In his opinion, the main pattern of this development is the growing role that CCU has in the protection of an individual's dignity, rights and freedoms. The Judge emphasized that the use by the CCU of the rule of law principle and the development of the "living law" judicial doctrine are important steps on the way towards the European standards of justice whose priorities lie in legal values rather than in the provisions of the law. S. Vdovichenko emphasized that in the analysis of laws (their certain provisions) on their constitutionality the CCU often stated in its decisions that

with the guide of ensuring human and civil rights and freedoms the legal regulation of certain legal relations must be in conformity with the Fundamental Law of Ukraine, primarily with the principle of the rule of law, particularly with such elements as fairness, the correspondence between the interests of individuals and the society, the effectiveness of the aim and means of legal regulation, the reasonableness and logic of the law, etc. ${ }^{140}$

Hence, "The Constitutional Court of Ukraine in its consideration of cases interprets the Fundamental Law of Ukraine in the spirit of the 'living constitution' guided by the principle of the rule of law and its elements" ('emphasis added'), ${ }_{1}^{141}$ concluded the Judge.

In this regard the doctrine occasionally features the elements of the CCU's positions as court precedents, more as quasi-precedents as a more accurate and balanced feature, given the traditions of the continental system and the absence of the recognized normative power of the Court. It is also suggested to use such a term as an interpretation precedent (precedent of interpretation) and an application of law's precedent (it would highlight the difference from the classic English court precedent as the result of law-making activity). The quasi-precedent is an act of some norm-making in the form of the Court's decision to revoke a nor-

140 Participation of CCU Judge S. Vdovichenko in the International Conference 'On the Role of Constitutional Review Bodies in Ensuring the Rule of Law in Rule-Making and LawEnforcement', official web-site of the Constitutional Court of Ukraine, Message of the press service of the Constitutional Court of Ukraine. [online]. Available at: <http://web.ccu.gov. ua/novyna/uchast-suddi-konstytuciynogo-sudu-ukrayiny-sergiya-vdovichenka-u-mizhnarodniy-konferenciyi-1> Accessed: 19.10.2019.

141 Id. 
mative and legal act that does not conform to the Constitution. B. Malyshev believes that "a quasi-precedent norm is a universally binding rule of behaviour established by the Court decision, namely in its operative part, in cases involving the constitutionality of a certain legal act [... ${ }^{\prime} .{ }^{142}$

At the same time, during the Second Congress of the Association of Constitutional Justice of the Countries of the Baltic and Black Sea Regions (BBCJ) held in June 2017 in Kharkiv 'On the Role of Constitutional Courts in Interpreting the Provisions of National Constitutions In the Context of the Generally Recognized Principles and Norms of International Law and EU Law, Judgments of International Courts', Yurii Baulin, the then acting Chairman of the Constitutional Court of Ukraine and the President of the Association of Constitutional Justice of the Countries of the Countries of the Baltic and Black Sea Regions, emphasized that

without extended and creative interpretation the Constitution risks remaining a program document that consists only of positive norms (the letter) with no account for its ideology (the spirit), i.e. the unwritten constitutional norms and values, devoid of which the act of the supreme legal force cannot serve as an effective instrument of limiting the state's power ('emphasis added'). ${ }^{143}$

Yu. Baulin made another comment stating that through official interpretations the body of constitutional jurisdiction has an objective influence on the law-making process, because interpretation acts also define the boundaries for understanding the constitutional regulations by the bodies of state government, local self-government bodies and everyone who has influence on the development of the national legal system, as well as the application of law in the sense of the implementation of legal norms. ${ }^{144}$

At the same time, the national legal and judicial practice does not have a lot of supporters for the dynamic approach, let alone the more comprehensive theoretical substantiation.

142 Малишев Б. В. Судовий прецедент у правовій системі Англії. Київ: Праксіс, 2008, 344 c. (MALYSHEV, Borys. Judicial Precedent in the English Legal System. Kyiv: Praksis, 2008, 344 p.)

143 BAULIN, Yurii. The Role of Constitutional Courts in Interpreting the Provisions of National Constitutions In the Context of the Generally Recognized Principles and Norms of International Law and EU Law, Judgments of International Courts. In Journal of the Association of Constitutional Justice of the Countries of the Baltic and Black Sea Regions: Proceedings from the Second Congress of the Association of Constitutional Justice of the Countries of the Baltic and Black Sea Regions (BBCJ). Kharkiv, Ukraine, June 01-02, 2017, p. 11 [online]. Available at: <https://www.osce.org/project-coordinator-inukraine/385824?download=true $>$ Accessed: 19.10.2019.

144 Id. 
4 The respect and enforcement of the judgments with 'law-making' elements in the practice of court actions: binding legal norms or non-binding guidelines?

Under the applicable laws of Ukraine a decision or an opinion of the CCU is binding, final and may not be appealed. However, despite the authority and respect enjoyed by the CCU, the practical implementation of its decisions faces certain problems. The main challenge in the way of the due implementation of the CCU's decisions is, in the words of Judge M. Markush, that the officials and state government bodies, as subjects of the law enforcement, ignore them. It results in their direct failure to comply, i.e. omission and refusal to take certain actions that they are bound to take but failed. ${ }^{145}$

\subsection{Case on administrative liability in the field of ensuring traffic safety}

So, in the Decision of 22 December 2010 (the case involving administrative responsibility in sphere of securing traffic safety), the CCU referring to the rule of law principle, the law-governed state principle and the presumption of innocence, has virtually found non-conforming to the Constitution of Ukraine the provisions of the Code of Ukraine on Administrative Offences. It made a note that "with the view of the rule of law principle the constitutional presumption of innocence of a person extends to charges of committing an administrative offence brought against this person" ${ }^{146}$

Under the Code of Ukraine on Administrative Offences (hereinafter - the Code):

in case of an administrative offence in the field of traffic safety that was recorded by automated special technical facilities which have functions of photo- and video-recording, film scanning, or facilities of photographing and filming as well as video-recording, the protocol of administrative offence shall not be drawn up, since the decision on the administrative offence is made in the absence of the person who faces administrative liability. ${ }^{147}$

145 Маркуш М. Шляхи підвищення ефективності виконання рішень Конституційного Суду України: теооретичні та практичні аспекти. Вісник Конституційного Суду України, 2009, № 5, с. 76-88 (MARKUSH, Mariia. The Ways to Improve the Effectiveness with which the Decisions by the Constitutional Court of Ukraine are Implemented: Theoretical and Practical Aspects. Constitutional Court Ukraine Bulletin, 2009, no. 5, pp. 76-88).

146 Decision of the Constitutional Court of Ukraine of 22 December 2010 no. 23-rp/2010. [online]. Available at: <https://zakon.rada.gov.ua/laws/show/v023p710-10> Accessed: 19.10.2019.

147 Id. 
While copies of the decision and the records in the case are sent to the person who faces administrative liability within three days from the date the decision is drawn up. ${ }^{148}$

In its Decision the CCU highlights the fact that this provision specifies the situation for bringing to administrative responsibility against owners (co-owners) of motor-vehicles, while there is a failure to provide the elements essential to the offence, that is why it cannot constitute the sole grounds for this liability. The types of offences and the procedure of bringing to administrative responsibility are specified in the Specific Part of the Code. Consequently, provisions specified by Article 14-1 of the Code may be applied only in the systemic conjunction with a number of other articles in the Specific Part of the Code whose dispositions unambiguously recognize the subject of liability for committing offences in the field of traffic safety as a person who is guilty of committing this offence, namely the driver of the vehicle. With no indication in the Specific Part of the Code that subjects of these offences are owners (co-owners) of vehicles, those subjects may be held liable for an administrative offence solely in situations where their actions have elements constituent of an administrative offence, all other situations contribute to legal uncertainty with regard to identifying the subject that is held liable in this field. In addition, under the Constitution of Ukraine legal liability of a person is of an individual nature. The need to make administrative liability individual is spelled out in the Code as well, it specified that the recovery of penalty should take into account the nature of the offence, the person of the offender, the extent of his or her guilt, the person's property status as well as the circumstances that attenuate or aggravate the liability. ${ }^{149}$

However, on 14 July 2015, the Law of Ukraine 'On Amendments to Certain Legislative Acts of Ukraine to Improve the Regulation of Relations in the Field of Ensuring Traffic Safety'150 was passed and it virtually renewed the revoked articles of the Code of Ukraine on Administrative Offences. This law directly contradicts the Decision by the CCU of 22 December 2010, that specified recommendations to the Verkhovna Rada of Ukraine to bring in conformity to the CCU's Decision the procedure regulating administrative liability for offences involving the breach of traffic safety in case they are recorded by automated technical facilities. At the same time the Main Scientific and Expert Department at the Staff of the Verkhovna Rada of Ukraine issued a Conclusion that directly indicated the

\section{Id.}

149 Decision of the Constitutional Court of Ukraine of 22 December 2010 no. 23-rp/2010.

150 Закон України 'Про внесення змін до деяких законодавчих актів України щодо вдосконалення регулювання відносин у сфері забезпечення безпеки дорожнього руху’ від 14 липня 2015 р. № 596-VIII. Відомості Верховної Ради (ВВР), 2015, № 39, ст.372 (The Law of Ukraine 'On Amendments to Certain Legislative Acts of Ukraine to Improve the Regulation of Relations in the Field of Ensuring Traffic Safety' no. 596-VIII of 14 July 2015. Bulletin of the Verkhovna Rada of Ukraine, 2015, no. 39, st.372). [online]. Available at: <https://zakon.rada.gov.ua/laws/show/596-19> Accessed: 19.10.2019. 
contradiction of these legal provisions with the Constitution and violation of the CCU's Decision still at the stage of drafting the law. The Parliament ignored it, nevertheless. The Verkhovna Rada Committee on Legislative Support of Law Enforcement recommended passing the respective draft law. ${ }^{151}$

\subsection{Case on mandatory state pension insurance}

Whereas in the Decision by the Supreme Court of Ukraine in the exemplary case of terminating the payment of pension benefits to internally displaced persons of 3 May 2018, ${ }^{152}$ the Supreme Court of Ukraine made a direct reference to the CCU's Decision of 7 October 2009, among other sources of law and enforcement acts in the decision of this case. With this particular decision the CCU declared unconstitutional the provisions of Clause 2, Paragraph 2, Article 49, second sentence of Article 51 of the Law of Ukraine 'On Mandatory State Pension Insurance' in part of terminating the payment of pension benefits for the whole time of the retired person's residence (stay) abroad, unless otherwise is stipulated in an international treaty to which Ukraine is a party, the Verkhovna Rada of Ukraine consented to the mandatory nature of this clause. The CCU stated in the Decision no. 25-rp/2009 that:

in contradiction with the constitutional guarantees for social protection of everyone who has the right to receive pensions in old age, pensioners, who have chosen their permanent place of residence in a country that has no respective Agreement concluded with Ukraine, have been denied this right at the legislative level. With the guide of the legal and social nature of pensions the right of a citizen to receive the pension granted to him or her cannot be associated with such a condition as permanent residence in Ukraine; guided by the constitutional principles the state is bound to guarantee this right regardless of the fact whether the person who was granted this pension resides in Ukraine or abroad ('emphasis added'). ${ }^{153}$

\subsection{Case on illegal removal of the former Prosecutor General of Ukraine from} the office

The Decision by Kyiv City District Court in the case of former Prosecutor General S. Piskun seems to be rather interesting. On 18 November 2005, the

151 Dissenting opinion of CCU Judge Slidenko I. D. on the Decision of the Constitutional Court of Ukraine of 26 April 2018 no. 4-r/2018. [online]. Available at: <https://zakon.rada. gov.ua/laws/show/ne04d710-18/sp:max15?sp=:max15\&lang=uk> Accessed: 19.10.2019.

152 Decision of the Supreme Court of Ukraine in the exemplary case of the suspension of pension to an internally displaced person of 3 May 2018. Case no. 805/402/18. [online]. Available at: <http://search.ligazakon.ua/l_doc2.nsf/link1/VS180769.html> Accessed: 19.10.2019.

153 Decision of the Constitutional Court of Ukraine of 7 October 2009 no. 25-rp/2009. [online]. Available at: <https://zakon.rada.gov.ua/laws/show/v025p710-09> Accessed: 19.10.2019. 
court had an open hearing of the case involving an administrative lawsuit filed by S.V. Piskun against the President of Ukraine to find the Decree no. 1441/2002 'On Removal of S. Piskun from the office of the Prosecutor General of Ukraine' of 14 October 2015 illegal, the court revoked it and proscribed the reinstatement of the person back to his office. ${ }^{154}$ In its Decision the Court was guided by the Decision of the CCU no. 8-rp/2002 and made the following conclusion:

[...] with the guide of the above, there is no reason to believe that certain norms of the Labour Code of Ukraine cannot be applied to Members of the Cabinet of Ministers of Ukraine, heads of other bodies with the central executive state government bodies and officials who are appointed to or removed from their respective positions by the President of Ukraine or the Verkhovna Rada of Ukraine pursuant to the Constitution of Ukraine. Under Article 11 of the Law of Ukraine 'On Civil Service' public officials have the right to protect their legal rights and interests with the superior state government bodies and in the court of law, and they have the right to appeal directly with the court the decisions on the termination of their public service [...] ('emphasis added'). ${ }^{155}$

In addition,

The Court cannot accept the reasons cited by the defendant's counsel claiming that the office of the Prosecutor General of Ukraine is a political one as it will contradict the norms specified by Article 121 of the Constitution of Ukraine, Articles 2, 3, 5, 6, 7 of the Law of Ukraine 'On the Public Prosecutor's Office' regarding the list of functions performed by the Prosecutor's Office of Ukraine, the Prosecutor's Office's own jurisdiction and independence from state government bodies with the exception for the Verkhovna Rada of Ukraine and the only case of constitutional accountability exclusively to the Verkhovna Rada of Ukraine under Article 122 of the Constitution of Ukraine, according to the Decision by the Constitutional Court of Ukraine no. 8-rp/2002. In addition, Article 3 of the Code of Administrative Proceedings of Ukraine in its definition of the term 'the civil service' differentiates political offices and prosecutors ('emphasis added'). ${ }^{156}$

Hence, in this case the Court arrived at the opinion that the President's Decree 'On Removal of S. Piskun from the office of the Prosecutor General of

154 Decision of the Shevchenkivskyi District Court of Kyiv City in the case of former Prosecutor General S. Piskun of 18 November 2005. Case no. 2-12238/05. [online]. Available at: <http://khpg.org/index.php?id=1133441864> Accessed: 19.10.2019.

155 Decision of the Constitutional Court of Ukraine of 7 May 2002 no. 8-rp/2002. [online]. Available at: <https://zakon.rada.gov.ua/laws/show/ru/v008p710-02/ed20060101> Accessed: 19.10.2019.

156 Decision of the Shevchenkivskyi District Court of Kyiv City in the case of former Prosecutor General S. Piskun of 18 November 2005. Case no. 2-12238/05. 
Ukraine' is illegal and the defendant's rights are to be protected through the revocation of the Law in question and reinstatement of the defendant in the office of the Prosecutor General of Ukraine. ${ }^{157}$

\subsection{Case on the advance notice of holding a peaceful assembly}

In the same way, the Decision of the CCU of 19 April 2001 no. 4-rp/2001 (the case involving timely notification on peaceful gatherings) makes a clear statement that "setting of specific terms for the advance notice of holding peaceful assemblies with the account for their forms, their scale, the venue and time of holding thereof, etc. is the subject for legislative regulation". ${ }^{158}$

Despite this ruling, the practice of passing acts by local governments to regulate the procedure of holding the respective events was quite common and thus limited the essence of this right to peaceful assemblies. Those particular acts, and not the Decision by the CCU, were referred to by the judges who passed the respective decisions (e.g. the Decision of the Kyiv City Circuit Administrative Court that banned peaceful assemblies in the period from 1 December 2013 to 7 January 2014 at the Maidan Nezalezhnosti and other streets, etc.). ${ }^{159}$

For instance, the Kyiv City Circuit Administrative Court issued the Ruling no. 25615099 of 13 August 2012, that recognized that the local council has the right "to consider issues regarding the procedure and the venue of holding meetings, rallies, manifestations, other mass events with the account for the interests of the territorial community members" (Decision no. 25615099 of 13 August 2012)..$^{160}$

Though these court decisions contradict the practice of the European Court of Human Rights. Particularly, in the case of 'Vyerentsov and others $v$. Ukraine' ECtHR stated that:

The procedures adopted by local government bodies to regulate the organization and holding of demonstrations in their respective areas seem to fail to provide the sufficient legal grounds for the same reason - there is no general act passed by the parliament which could be the foundation for the development of documents by local government bodies (Para. 54 of the Decision). ${ }^{161}$

157 Id.

158 Decision of the Constitutional Court of Ukraine of 9 April 2001 no. 4-rp/2001. [online]. Available at: <https://zakon.rada.gov.ua/laws/show/v004p710-01 > Accessed: 19.10.2019.

159 Unified Register of Court Decisions. [online]. Available at: <http://reyestr.court.gov.ua/> Accessed: 19.10.2019.

160 Id.

161 Vyerentsov and others v. Ukraine. ECtHR. Judgement of 11 April 2013. Application no. 20372/11. Official Bulletin of Ukraine, 2013, no. 83, p. 161, Art. 3106. [online]. Available at: <https://zakon.rada.gov.ua/laws/show/974_945> Accessed: 19.10.2019. 
On the other hand, some local and appellate courts have a more progressive position. There are cases when local regulations on holding peaceful assemblies were found illegal since the bodies that issued them exceeded their powers granted by the Constitution and the laws of Ukraine (the Decision of Kherson Circuit Administrative Court no. 26124845 of 18 September 2012, the Decision of Cherkasy Circuit Administrative Court no. 32917184 of 7 July 2013). Some local and appellate administrative courts do not enforce local regulations with the guide of the legality principle, despite the fact that those regulations have not been officially revoked (the Decision of Kyiv Appellate Administrative Court no. 36949796 of 23 January 2014). ${ }^{162}$

\section{Conclusions. The role and prospects of law-making activity of the CCU in Ukraine}

With the guide of the role and the main tasks of the CCU, especially following the introduction of the institution of a constitutional complaint in Ukraine, prompted, among other things, by the biggest number of applications (complaints) lodged with the ECtHR against Ukraine, the Constitutional Court of Ukraine can be compared with the European Court of Human Rights, since the grounds and the procedure for filing a constitutional complaint is similar to that of the European Court of Human Rights. It must be stated on a general note that the introduction of the institution of a constitutional complaint, which has been functioning in Europe for a long time, seems to be one of the greatest achievements of the constitutional reform in Ukraine. I am confident that it will bring down the number of applications lodged with the ECtHR by Ukrainian citizens; it will also reduce the workload burden on the whole court system.

It must be mentioned in this context that the main method for the interpretation of the ECHR is the dynamic interpretation method, which has been repeatedly used in the practice of the ECtHR. Namely, in the case 'Tyrer $v$. the United Kingdom' of 25 April 1978, the European Court of Human Rights made a description for the internal dynamic nature of the Convention referring to it as, "a living instrument, that [...] has to be interpreted in the view of the presentday conditions". 163 The Preamble to the ECHR reads that the Convention was adopted with the aim of further realization of human rights and fundamental

162 Куйбіда Р., Середа М. Свобода мирних зібрань у практииі адміністративних судів: аналітичний огляд судової практики за 2010-2014 роки. Центр політико-правових peформ. Київ, 2014 (KUIBIDA, Roman, SEREDA, Maksym. Freedom of Peaceful Assembly in the Practice of Administrative Courts: Analytic Overview of Judicial Practice Within the Period from 2010 to 2014. Centre of Policy and Legal Reform. Kyiv, 2014. [online]. Available at: <http://pravo.org.ua/files/Sud/__2010-2014.pdf> Accessed: 1.5.2019.

163 Tyrer v. the United Kingdom. ECtHR. Judgement of 25 April 1978. Application no. 5856/72. [online]. Available at: <https://hudoc.echr.coe.int/eng\#\{\%22fulltext $\% 22:[\% 22$ tyrer\%20 v.\%20the\%20united\%20Kingdom\%22],\%22itemid\%22:[\%22001-57587\%22]\}> Accessed: 19.10.2019. 
freedoms. ${ }^{164}$ It means that the rights enshrined in the ECHR must be interpreted with the view of the present-day conditions in order to be practical and effective. Sociological, technological and scientific changes, the developing standards in the field of human rights as well as the change in perceptions of the moral norms should all be taken into account in the application of the ECHR. ${ }^{165}$ That is why the ECtHR has changed a number of times its position on certain issues. For example, first, the European Court of Human Rights denied that the relations between same-sex couples is part of the sphere of family life pursuant to Article 8 ECHR (Mata Estevez v. Spain judgment). ${ }^{166}$ However, in the case of Schalk and Kopf v. Austria, the ECtHR admitted that same-sex couples enjoy the same level of protection of their family life with the view of the "rapid development of the attitude to the same-sex couples in many member-states of the Council of Europe, and with the account for a growing trend to include same-sex couples in the definition of 'family' in the legislation of the European Union". ${ }^{167}$ Here the European Court of Human Rights used the evolutionary method of interpreting the ECHR.

With this guide it is quite logical for the Constitutional Court of Ukraine to use the dynamic (evolutionary) method in the interpretation of the Constitution of Ukraine. Moreover, in its own practice the European Court of Human Rights has developed the 'margin of appreciation' doctrine (Handyside v. the United Kingdom judgment $)^{168}$, under this doctrine the states use the 'margin of appreciation', they have the benefit of assessment (definition, interpretation) of certain events, facts, situations or any other phenomena within their own jurisdiction. ${ }^{169}$ The European Court of Human Rights has repeatedly stressed that the national bodies of state government and courts enjoy the supremacy in their assessment of

164 European Convention on Human Rights of 4 November 1950 (as amended by Protocols Nos. 11 and 14, supplemented by Protocols Nos. 1, 4, 6, 7, 12 and 13). European Court of Human Rights, Council of Europe, p. 5. [online]. Available at: <http://www.echr.coe.int/ Documents/Convention_ENG.pdf> Accessed: 19.10.2019.

165 SPIELMANN, Dean. Allowing the right Margin the European Court of Human Rights and the National Margin of Appreciation Doctrine: Waiver or Subsidiarity of European Review? In Working Paper Series of the Centre for European Legal Studies (CELS). University of Cambridge, Faculty of law, 2012, p. 18.

166 Mata Estevez v. Spain. ECtHR. Judgement of 10 May 2001. Reports of Judgments and Decisions 2001-VI. Application no. 56501/00. [online]. Available at: <http://hudoc.echr.coe. int/eng?i=001-22334> Accessed: 19.10.2019.

167 Schalk and Kopf v. Austria. ECtHR. Judgement of 22 November 2010. Reports of Judgments and Decisions 2010. Application no. 30141/04. [online]. Available at: <https:// hudoc.echr.coe.int/eng\#\{\%22itemid\%22:[\%22001-99605\%22]\}> Accessed: 19.10.2019.

168 Handyside v. the United Kingdom. EctHR. Judgement of 7 December 1976. Application no. 5493/72. [online]. Available at: <https://hudoc.echr.coe.int/eng\#\{\%22item id\%22:[\%22001-57499\%22]\}> Accessed: 19.10.2019.

169 ECHR - Introduction. Hembach Legal, The Business of Human Rights. [online]. Available at: <http://echr-online.info/echr-introduction/> Accessed: 19.10.2019. 
facts and interpretation of the national law. ${ }^{170}$ At the same time former President of the ECtHR D. Spielmann notes that in applying this essentially judge-made doctrine of 'margin of appreciation', the Court imposes self-restraint on its power of review, accepting that domestic authorities are best placed to settle a dispute. ${ }^{171}$

Within this context, from the practical standpoint and the perspective of the legally granted powers, the Constitutional Court of Ukraine enjoys a rather wide and even unlimited 'power of discretion' in its interpreting of the Constitution of Ukraine. The role of the CCU in the development of law should not be underestimated and reduced solely to the simple application of constitutional norms, which by the way, have the most abstract and evaluative nature, even in comparison with regular laws. Today the key issue lies in the willingness of the CCU Judges to assume this responsibility, to be active participants and normative 'developers' of law and to implement the European legal values and principles within the legal system of Ukraine, along with their willingness to generate really good, argumentative and well-reasoned decisions that will largely affect the Court's authority and the general level of trust that the judicial power enjoys. In addition, the CCU has to be one of the main subjects in the development of the national legal doctrine, it has to influence and promote the progress in the legal field.

So, I believe that the Constitutional Court of Ukraine has an extremely important role in the development of Ukraine's legal system and it has to promote the dynamic interpretation of law. In order to ensure the supremacy of the Constitution of Ukraine, the CCU has to take into account the trends in the development of the society and law. Currently we can de facto observe the application of some elements of the law-making in the practice of the CCU. That is why I am confident that in the future one of the main areas in the development of the CCU's operation will be the expansion of its law-making activity, which is extremely important in the context of convergence of different legal systems, cultures and protections for human rights and freedoms.

\section{References}

BAULIN, Yurii. The Role of Constitutional Courts in Interpreting the Provisions of National Constitutions In the Context of the Generally Recognized Principles and Norms of International Law and EU Law, Judgments of International Courts. In Journal of the Association of Constitutional Justice of the Countries of the Baltic and Black Sea Regions: Proceedings from the Second Congress of the Association of Constitutional Justice of the Countries of the Baltic and Black Sea Regions (BBCJ). Kharkiv, Ukraine, June 01-02, 2017, pp. $10-13$. [online]. Available at: <https://www.osce. org/project-coordinator-in-ukraine/385824?download=true $>$ Accessed: 19.10.2019.

Constitution of Ukraine, adopted 28 June 1996, no. 254K/96-BP. Bulletin of the Verkhovna

Rada of Ukraine, 1996, no. 30, st.141. [online]. Available at: <https://zakon.rada.gov. ua/laws/show/254\%D0\%BA/96-\%D0\%B2\%D1\%80> Accessed: 19.10.2019.

170 SPIELMANN, Dean, 2012, pp. 8-9.

171 Id., pp. 2-3. 
DENKOVYCH, Olha. Object and Subject in the Interpretations Made by the Constitutional Court of Ukraine in the Criminal Law. Visnyk of the Lviv University. Series Law, 2011, vol. 52, pp. 309-318.

Decision of the Constitutional Court of Ukraine of 3 December 1998 no. 17-rp/98. [online]. Available at: <https://zakon.rada.gov.ua/laws/show/v017p710-98> Accessed: 19.10.2019.

Decision of the Constitutional Court of Ukraine of 26 February 1998 no. 1-rp/98. [online]. Available at: <https://zakon.rada.gov.ua/laws/show/v001p710-98> Accessed: 19.10.2019.

Decision of the Constitutional Court of Ukraine of 25 March 1998 no. 3-rp/98. The Official Bulletin of Ukraine, 1998, no. 23, p. 110, Art. 852, Act Code 5486/1998. [online]. Available at: <https://zakon.rada.gov.ua/laws/show/v003p710-98> Accessed: 19.10.2019.

Decision of the Constitutional Court of Ukraine of 29 December 1999 no. 11-rp/99. [online]. Available at: <https://zakon.rada.gov.ua/laws/show/v011p710-99> Accessed: 19.10.2019.

Decision of the Constitutional Court of Ukraine of 25 October 2000 no. 12-rp/2000. [online]. Available at:<https://zakon.rada.gov.ua/laws/show/v012p710-00 > Accessed: 19.10.2019.

Decision of the Constitutional Court of Ukraine of 14 December 2000 no. 15-rp/2000. [online]. Available at: <https://zakon.rada.gov.ua/laws/show/v015p710-00> Accessed: 19.10.2019.

Decision of the Constitutional Court of Ukraine of 9 April 2001 no. 4-rp/2001. [online]. Available at: <https://zakon.rada.gov.ua/laws/show/v004p710-01> Accessed: 19.10.2019.

Decision of the Constitutional Court of Ukraine of 20 March 2002 no. 5-rp/2002. [online]. Available at: <https://zakon.rada.gov.ua/laws/show/v005p710-02> Accessed: 19.10.2019.

Decision of the Constitutional Court of Ukraine of 7 May 2002 no. 8-rp/2002. [online]. Available at: <https://zakon.rada.gov.ua/laws/show/ru/v008p710-02/ed20060101> Accessed: 19.10.2019.

Decision of the Constitutional Court of Ukraine of 29 May 2002 no. 10-rp/2002. [online]. Available at: <https://zakon.rada.gov.ua/laws/show/v010p710-02> Accessed: 19.10.2019.

Decision of the Constitutional Court of Ukraine of 9 July 2002 no. 15-rp/2002. [online]. Available at: <https://zakon.rada.gov.ua/laws/show/v015p710-02> Accessed: 19.10.2019.

Decision of the Constitutional Court of Ukraine of 2 November 2004 no. 15-rp/2004. [online]. Available at: <https://zakon.rada.gov.ua/laws/show/v015p710-04> Accessed: 19.10.2019.

Decision of the Constitutional Court of Ukraine of 22 September 2005 no. 5-rp/2005. [online]. Available at: <https://zakon.rada.gov.ua/laws/show/v005p710-05> Accessed: 19.10.2019.

Decision of the Constitutional Court of Ukraine of 20 June 2007 no. 5-rp/2007. [online]. Available at: <https://zakon.rada.gov.ua/laws/show/v005p710-07> Accessed: 19.10.2019.

Decision of the Constitutional Court of Ukraine of 9 July 2007 no. 6-rp/2007. [online]. Available at: <https://zakon.rada.gov.ua/laws/show/v0a6p710-07> Accessed: 19.10.2019.

Decision of the Constitutional Court of Ukraine of 8 October 2008 no. 20-rp/2008. 
[online]. Available at: <https://zakon.rada.gov.ua/laws/show/v020p710-08> Accessed: 19.10.2019.

Decision of the Constitutional Court of Ukraine of 7 October 2009 no. 25-rp/2009. [online]. Available at: <https://zakon.rada.gov.ua/laws/show/v025p710-09> Accessed: 19.10.2019.

Decision of the Constitutional Court of Ukraine of 11 March 2010 no. 7-rp/2010. [online]. Available at: <https://zakon.rada.gov.ua/laws/show/v007p710-10> Accessed: 19.10.2019.

Decision of the Constitutional Court of Ukraine of 30 September 2010 no. 20-rp/2010. [online]. Available at: <https://zakon.rada.gov.ua/laws/show/v020p710-10> Accessed: 19.10.2019.

Decision of the Constitutional Court of Ukraine of 22 December 2010 no. 23-rp/2010. [online]. Available at: <https://zakon.rada.gov.ua/laws/show/v023p710-10> Accessed: 19.10.2019.

Decision of the Constitutional Court of Ukraine of 11 March 2011 no. 2-rp/2011. [online]. Available at: <https://zakon.rada.gov.ua/laws/show/v002p710-11> Accessed: 19.10.2019.

Decision of the Constitutional Court of Ukraine of 14 December 2011 no. 18-rp/2011. [online]. Available at: <https://zakon.rada.gov.ua/laws/show/v018p710-11> Accessed: 19.10.2019.

Decision of the Constitutional Court of Ukraine of 26 December 2011 no. 20-rp/2011. [online]. Available at: <https://zakon.rada.gov.ua/laws/show/v020p710-11> Accessed: 19.10.2019.

Decision of the Constitutional Court of Ukraine of 13 March 2012 no. 5-rp/2012. [online]. Available at: <https://zakon.rada.gov.ua/laws/show/v005p710-12> Accessed: 19.10.2019.

Decision of the Constitutional Court of Ukraine of 1 June 2016 no. 2-rp/2016. [online]. Available at: <https://zakon.rada.gov.ua/laws/show/en/v002p710-16\#n17> Accessed: 19.10.2019.

Decision of the Constitutional Court of Ukraine of 17 July 2018 no. 6-r/2018. [online]. Available at: <https://zakon.rada.gov.ua/laws/show/v006p710-18> Accessed: 19.10.2019.

Decision of the Constitutional Court of Ukraine of 20 December 2018 no. 13-r/2018. [online]. Available at: <https://zakon.rada.gov.ua/laws/show/v013p710-18\#n2> Accessed: 19.10.2019.

Decision of the Constitutional Court of Ukraine of 26 February 2019 no. 1-r/2019. [online]. Available at: <https://zakon.rada.gov.ua/laws/show/v001p710-19> Accessed: 19.10.2019.

Decision of the Shevchenkivskyi District Court of Kyiv City in the case of former Prosecutor General S. Piskun of 18 November 2005. Case no. 2-12238/05. [online]. Available at: <http://khpg.org/index.php?id=1133441864> Accessed: 19.10.2019.

Decision of the Supreme Court of Ukraine in the exemplary case of the suspension of pension to an internally displaced person of 3 May 2018. Case no. 805/402/18. [online]. Available at: <http://search.ligazakon.ua/__doc2.nsf/link1/VS180769.html> Accessed: 19.10.2019.

Dissenting opinion of CCU Judge Slidenko I. D. on the Decision of the Constitutional Court of Ukraine of 1 June 2016 no. 2-rp/2016. [online]. Available at: <https://zakon.rada.gov. ua/laws/show/nba2d710-16> Accessed: 19.10.2019. 
Dissenting opinion of CCU Judge Shaptala N. K. on the Decision of the Constitutional Court of Ukraine of 1 June 2016 no. 2-rp/2016. [online]. Available at: <https://zakon. rada.gov.ua/laws/show/en/nca2d710-16\#n3> Accessed: 19.10.2019.

Dissenting opinion of CCU Judge Slidenko I. D. on the Decision of the Constitutional Court of Ukraine of 26 April 2018 no. 4-r/2018. [online]. Available at: <https://zakon. rada.gov.ua/laws/show/ne04d710-18/sp:max15?sp=:max15\&lang=uk> Accessed: 19.10.2019.

Dissenting opinion of CCU Judge Lemak V. V. on the Decision of the Constitutional Court of Ukraine of 26 February 2019 no. 1-r/2019. [online]. Available at: <https:// zakon.rada.gov.ua/laws/show/nd01d710-19\#n56> Accessed: 19.10.2019.

Dissenting opinion of CCU Judge Shevchuk S.V. on the Decision of the Constitutional Court of Ukraine of 26 February 2019 no. 1-r/2019. [online]. Available at: <https:// zakon.rada.gov.ua/laws/show/nh01d710-19\#n2> Accessed: 19.10.2019.

ECHR - Introduction. Hembach Legal, The Business of Human Rights. [online]. Available at: <http://echr-online.info/echr-introduction/> Accessed: 19.10.2019.

European Convention on Human Rights of 4 November 1950 (as amended by Protocols Nos. 11 and 14, supplemented by Protocols Nos. 1, 4, 6, 7, 12 and 13). European Court of Human Rights, Council of Europe, 62 p. [online]. Available at: <http://www.echr. coe.int/Documents/Convention_ENG.pdf $>$ Accessed: 19.10.2019.

Handyside v. the United Kingdom. ECtHR. Judgement of 7 December 1976. Application no. 5493/72. [online]. Available at: <https://hudoc.echr.coe.int/eng\#\{\%22item id\%22:[\%22001-57499\%22]\}> Accessed: 19.10.2019.

HONCHAROV, Volodymyr. From the Old to the New Theory of Interpretation: the Main Challenges and Solutions. Philosophy of Law and the General Theory of Law, 2014, no. 1-2, pp. 53-69.

KOTENKO, Mykola. Systematic interpretation and its role in the law-interpretational activities of the Constitutional Court of Ukraine. Scientific Journal "Chronicles of KUL", 2015, no. 2, pp. 61-67.

KUIBIDA, Roman, SEREDA, Maksym. Freedom of Peaceful Assembly in the Practice of Administrative Courts: Analytic Overview of Judicial Practice Within the Period from 2010 to 2014. Centre of Policy and Legal Reform. Kyiv, 2014, 23 p. [online]. Available at: <http://pravo.org.ua/files/Sud/__2010-2014.pdf> Accessed: 19.10.2019.

MALYSHEV, Borys. Judicial Precedent in the English Legal System. Kyiv: Praksis, 2008, $344 \mathrm{p}$.

MARKUSH, Mariia. The Ways to Improve the Effectiveness with which the Decisions by the Constitutional Court of Ukraine are Implemented: Theoretical and Practical Aspects. Constitutional Court Ukraine Bulletin, 2009, no. 5, pp. 76-88.

MARTYNIUK, Roman. The Legal Nature and Judicial Characteristics of the Acts of the Constitutional Court of Ukraine. Entrepreneurship, Economy and Law, 2008, no. 1, pp. 3-6.

Mata Estevez v. Spain. ECtHR. Judgement of 10 May 2001. Reports of Judgments and Decisions 2001-VI. Application no. 56501/00. [online]. Available at: <http://hudoc. echr.coe.int/eng?i=001-22334> Accessed: 19.10.2019.

MIROSHNYCHENKO, Anatolii. Static and Dynamic Interpretation of Law. Law and Civil Society, 2012, no. 1, pp. 59-66.

National Report of the Constitutional Court of Ukraine 'On the Problems of Legislative Omission in Constitutional Jurisprudence', 21 p. [online]. Available at: <http://www. confeuconstco.org/reports/rep-xiv/report_Ukraine_uk.pdf> Accessed: 19.10.2019. 
National Report of the Constitutional Court of Ukraine. In Proceedings from XVI Congress of the Conference of European Constitutional Courts 'Co-operation of Constitutional Courts in Europe - Current Situation and Perspectives'. Kyiv, 2013, 32 p. [online]. Available at: <http://www.confeuconstco.org/reports/rep-xvi/LB-Ukraine-MS.pdf> Accessed: 19.10.2019.

Opinion of the Venice Commission On the Constitutional Situation in Ukraine no. 599/2010 of 17-18 December 2010 (CDL-AD(2010)04), 12 p. [online]. Available at: $\quad<$ https://www.venice.coe.int/webforms/documents/default.aspx?pdffile=CDL$\mathrm{AD}(2010) 044-\mathrm{e}>$ Accessed: 19.10.2019.

Participation of CCU Judge S. Vdovichenko in the International Conference 'On the Role of Constitutional Review Bodies in Ensuring the Rule of Law in Rule-Making and Law-Enforcement', official web-site of the Constitutional Court of Ukraine, Message of the press service of the Constitutional Court of Ukraine. [online]. Available at: $<$ http://web.ccu.gov.ua/novyna/uchast-suddi-konstytuciynogo-sudu-ukrayiny-sergiya-vdovichenka-u-mizhnarodniy-konferenciyi-1> Accessed: 19.10.2019.

Regulation 'On the Secretariat of the Constitutional Court of Ukraine' of 21 December 2011, adopted by the Decision of the Constitutional Court of Ukraine no. 26-p/2011. Official web-site of the Constitutional Court of Ukraine). [online]. Available at: <http:// www.ccu.gov.ua/docs/179> Accessed: 19.10.2019.

Resolution of the Constitutional Court of Ukraine of 30 November 2006 no. 16-y/2006. [online]. Available at: <https://zakon.rada.gov.ua/laws/show/v016u710-06/ sp:max25> Accessed: 19.10.2019.

Ruling of the Constitutional Court of Ukraine of 10 July 1998 no. 41-y/98. [online]. Available at: <https://zakon.rada.gov.ua/laws/show/v041u710-98> Accessed: 19.10.2019.

Ruling of the Constitutional Court of Ukraine of 31 March 2010 no. 15-y/2010. [online]. Available at: <https://zakon.rada.gov.ua/laws/show/v015u710-10> Accessed: 19.10.2019.

Ruling of the Constitutional Court of Ukraine of 15 January 2004 no. 1-y/2004. [online]. Available at: <https://zakon.rada.gov.ua/laws/show/v001u710-04> Accessed: 19.10.2019.

Ruling of the Constitutional Court of Ukraine of 29 August 2018 no. 50-y/2018. [online]. Available at: <https://zakon.rada.gov.ua/laws/show/v050u710-18> Accessed: 19.10.2019.

SAVIGNY, Friedrich Karl von. System des heutigen Römischen Rechts. Berlin: Veit und Comp., 1840.

Schalk and Kopf v. Austria. ECtHR. Judgement of 22 November 2010. Reports of Judgments and Decisions 2010. Application no. 30141/04. [online]. Available at: $<\mathrm{htt}-$ ps://hudoc.echr.coe.int/eng\#\{\%22itemid\%22:[\%22001-99605\%22]\}> Accessed: 19.10.2019.

SELIVANOV, Anatolii, STRYZHAK, Andrii. On Theoretical Issues of Constitutional Justice in Ukraine: Relevant Questions on the Current Development of the Constitutional Justice. Kyiv: Lohos, 2010, 276 p.

SHAPOVAL, Volodymyr. Establishment of the Constitutional Jurisdiction in Ukraine. Constitutional State, 1998, no. 9, pp. 110-116.

SHAPOVAL, Volodymyr. Establishment of the Constitutionalsim in Ukraine: Theoretical Problems. Law of Ukraine, 1998, no. 5, pp. 25-29.

SHAPOVAL, Volodymyr. The Constitutional Court of Ukraine. In SMOLII, Valerii (ed). Encyclopedia of Ukraine's History. Kyiv: Naukova Dumka, 2008, vol. 5, pp. 73-75. 
SHEMSHUCHENKO, Yurii, POHORILKO, Viktor. On Problems of Functions Performed by the Constitutional Court of Ukraine. Constitutional Court Ukraine Bulletin, 2002, no. 2, pp. 54-56.

SHEVCHUK, Stanislav. On the Binding Nature of the Decisions of the Constitutional Court of Ukraine Within the Context of the Doctrine of Judicial Precedent. Law of Ukraine, 2000, no. 2, pp. 45-48.

SHEVCHUK, Stanislav. General Theoretical Problems of Normativity of the Judicial Power Acts: Abstract of the Thesis for the Doctor Habilitatus degree: 12.00.01, Yaroslav the Wise National Law Academy of Ukraine, Kharkiv, 2008, 38 p.

SHEVCHUK, Stanislav. General Theoretical Problems of Normativity of the Judicial Power Acts [Text]: Thesis for the Doctor Habilitatus degree: 12.00.01, Kharkiv, Ukraine: Yaroslav Mudryi National Law Academy, 2008, 433 p.

SHEVCHUK, Stanislav. The Constitution Is Not Only a Text, But Values And the Spirit As Well. Judicial Power of Ukraine, messages of the Court's press service. [online]. Available at: <https://court.gov.ua/press/news/481840/> Accessed: 19.10.2019.

SKRYPNIUK, Oleksandr. Legal Acts of the Constitutional Court of Ukraine as a Source of the Modern Constitutional Law in Ukraine. Law of Ukraine, 2012, no. 3-4, pp. 404410.

SPIELMANN, Dean. Allowing the right Margin the European Court of Human Rights and the National Margin of Appreciation Doctrine: Waiver or Subsidiarity of European Review? In Working Paper Series of the Centre for European Legal Studies (CELS). University of Cambridge, Faculty of law, 2012, 30 p.

TESLENKO, Myroslava. Constitutional Jurisdiction in Ukraine. Kyiv: Shkola, 2003, 256 p. The Law of Ukraine 'On Psychiatric Aid' no. 1489-VIII of 22 February 2000. Bulletin of the Verkhovna Rada of Ukraine, 2000, no. 19, st.143, Art. 13, Para. 1). [online]. Available at: <https://zakon.rada.gov.ua/laws/show/1489-14> Accessed: 19.10.2019.

The Law of Ukraine 'On the Fulfillment of Decisions and Application of Practice of the European Court of Human Rights' of 23 February 2006 no. 3477-IV. Bulletin of the Verkhovna Rada of Ukraine, 2006, no. 30, st.260). [online]. Available at: <https:// zakon.rada.gov.ua/laws/show/3477-15> Accessed: 19.10.2019.

The Law of Ukraine 'On the Rules of Procedure of the Verkhovna Rada of Ukraine' of 10 November 2010 no. 1861-VI. Bulletin of the Verkhovna Rada of Ukraine, 2010, no. $14-15$, no. 16-17, st.133. [online]. Available at: <https://zakon.rada.gov.ua/laws/ show/1861-17?find=1\&text=\%CA\%EE\%ED\%F1\%F2\%E8\%F2\%F3\%F6\%B3\%E9\%E D\%E8\%E9+\%F1\%F3\%E4\#w11> Accessed: 19.10.2019.

The Law of Ukraine 'On Ensuring the Right to a Fair Trial' no. 192-VIII of 12 February 2015. Bulletin of the Verkhovna Rada of Ukraine, 2015, no. 18, no. 19-20, st.132. [online]. Available at: <https://zakon.rada.gov.ua/laws/show/192-19> Accessed: 19.10.2019.

The Law of Ukraine 'On Amendments to Certain Legislative Acts of Ukraine to Improve the Regulation of Relations in the Field of Ensuring Traffic Safety' no. 596-VIII of 14 July 2015. Bulletin of the Verkhovna Rada of Ukraine, 2015, no. 39, st.372. [online]. Available at: <https://zakon.rada.gov.ua/laws/show/596-19> Accessed: 19.10.2019.

The Law of Ukraine 'On Judiciary and the Status of Judges' no. 1402-VIII of 2 June 2016. Bulletin of the Verkhovna Rada of Ukraine, 2016, no. 31, st.545. [online]. Available at: <https://zakon.rada.gov.ua/laws/show/1402-19> Accessed: 19.10.2019.

The Law of Ukraine 'On the High Council of Justice' no. 1798-VIII of 21 December 2016. Bulletin of the Verkhovna Rada of Ukraine, 2017, no. 7-8, st.50. [online]. Available at: 
$<$ https://zakon.rada.gov.ua/laws/show/1798-19> Accessed: 19.10.2019.

The Law of Ukraine 'On the Constitutional Court of Ukraine' no. 2136-VIII of 13 July 2017. Bulletin of the Verkhovna Rada of Ukraine, 2017, no. 35, st.376. [online]. Available at: <https://zakon.rada.gov.ua/laws/show/2136-19> Accessed: 19.10.2019.

The Law of Ukraine 'On Amendments to Certain Legislative Acts of Ukraine on Providing Psychiatric Aid' no. 2205-VIII of 14 November 2017. Bulletin of the Verkhovna Rada of Ukraine, 2017, no. 51-52, st.448, Art. 13, Para. 1. [online]. Available at: <https://zakon.rada.gov.ua/laws/show/2205-19> Accessed: 19.10.2019.

The Law of Ukraine 'On the High Anti-Corruption Court of Ukraine' no. 2447-VIII of 7 June 2018. Bulletin of the Verkhovna Rada of Ukraine, 2018, no. 24, st.212). [online]. Available at: <https://zakon.rada.gov.ua/laws/show/2447-19> Accessed: 19.10.2019.

TOPCHII, Vasyl. The Official Interpretation of the Constitutional Provisions of Human Rights in the Paradigm of Legal Hermeneutics. Public Law, 2016, no. 1 (21), pp. $276-$ 283.

TSVIK, Marko. On the System of Judicial Acts. Journal of the National Academy of Legal Sciences of Ukraine, 2002, no. 4 (31) pp. $14-24$.

TYKHYI, Volodymyr. Judicial Interpretations by the Constitutional Court of Ukraine and the Legal Nature of its Decisions. Constitutional Court Ukraine Bulletin, 2001, no. 1, pp. 62-71.

TYKHYI, Volodymyr. The Effect of the Decisions by the Constitutional Court of Ukraine Over Time. Constitutional Court Ukraine Bulletin, 2001, no. 5, pp. 51 -54.

TYKHYI, Volodymyr. The Legal Nature of the Constitutional Court of Ukraine, its Powers, Decisions and Conclusions. Law of Ukraine, 2012, no. 1-2, pp. 97-111.

Tyrer v. the United Kingdom. ECtHR. Judgement of 25 April 1978. Application no. 5856/72. [online]. Available at: <https://hudoc.echr.coe.int/ eng\#\{\%22fulltext\%22:[\%22tyrer\%20v.\%20the\%20united\%20Kingdom\%22],\%22item id\%22:[\%22001-57587\%22]\}> Accessed: 19.10.2019.

Unified Register of Court Decisions. [online]. Available at: <http://reyestr.court.gov.ua/> Accessed: 19.10.2019.

Vyerentsov and others v. Ukraine. ECtHR. Judgement of 11 April 2013. Application no. 20372/11. Official Bulletin of Ukraine, 2013, no. 83, p. 161, Art. 3106. [online]. Available at: <https://zakon.rada.gov.ua/laws/show/974_945> Accessed: 19.10.2019.

YEVHRAFOV, Pavlo. Judicial Interpretations by the European Court of Human Rights and Their Significance for Ukraine. Jurisprudentia: Internet-Edition 'Jurisprudence online'. [online]. Available at: <https://www.lawyer.org.ua/?i=12> Accessed: 19.10.2019.

YEVHRAFOVA, Yelyzaveta. Acts of the Constitutional Court of Ukraine Within the System of the National Legislation. Law of Ukraine, 2001, no. 10, pp. 66-68. 